\title{
Hebrew Manuscript Painting in Late Medieval Spain: Signs of a Culture in Transition
}

\author{
Katrin Kogman-Appel
}

Two different worlds present themselves to the scholar of Hebrew illuminated manuscripts from Spain. Two distinct artistic idioms reflect the history of Spanish medieval Jewry, its cultural identities, its socioeconomic background, and its religious and ideological struggles. One is nonfigurative, nonnarrative, an almost aniconic idiom, with a clear preference for ornament in a style that reveals strong Islamic influence (Fig. 1). The second tells the story of ancient Israel in a richly narrative, figurative mode, while in style it echoes in every respect the artistic taste of Christian Europe (Fig. 14). ${ }^{1}$

Neither dates nor provenances can convincingly explain the development of these distinct artistic languages within the Jewish art of the Iberian Peninsula. They largely overlap, the Islamicizing aniconic idiom appearing about the 1230s in Castile, about 1300 in Roussillon, and then spreading to Catalonia and Aragon, where it remained popular throughout the fourteenth century; the other, more limited in time span and region, developed in Castile in the late thirteenth century and flourished in Catalonia between 1320 and approximately 1375 . None of the examples of this latter group is dated or bears an indication of origin, but prior research has placed them in these particular artistic environments and time frames.

The Islamicizing decoration is typical of a group of Bible manuscripts; its dominant features are elaborate carpet pages-full page, abstract, aniconic decorations recalling the design of carpets-along with various other kinds of ornamentation. At some later stage a flat, rather abstract representation of the temple implements was added (Figs. 2, 3). The figurative cycles, on the other hand, depicting the story of the Israelites as told in the books of Genesis and Exodus, decorate a group of Passover Haggadot, small volumes containing the liturgical text to be read at the Passover ritual meal. However, instead of accompanying the text and referring to the written account of the salvation of the children of Israel from Egyptian bondage, they appear as separate cycles, disconnected from the text-a narrative told in a pictorial language independently of the written word. Whereas before its appearance in Spain about 1230 the decorated Hebrew Bible already had a century-long tradition in the Middle East, the illustrated Passover Haggadah emerged in Europe as a new type of book about $1300 .^{2}$ Indeed, it had not become a separate volume until the thirteenth century, having formerly been a part of the general prayer book.

At first sight, the presence of two different modes for different types of books would seem sufficient to explain the phenomenon of two such different artistic tastes existing side by side, an approach pursued frequently in past scholarship. ${ }^{3}$ The two idioms were also presented in terms of artistic development and chronology, ${ }^{4}$ a point of view that somewhat eclipses the physical evidence, since it tends to overlook the continuation of the Islamicizing aniconic idiom in four- teenth-century Catalonia that parallels the figurative Haggadah cycles-not only at the same time but also in the same region and probably even in the same workshops. ${ }^{5}$

It might be assumed that the aniconic attitude in Jewish art was guided by a strict observation of the Second Commandment (Ex. 20:4): "You must not make a carved image for yourself, nor the likeness of anything in the heavens above, or on the earth below, or in the waters under the earth." 7 The avoidance of figurative motifs, however, seems to come from the Islamic aniconic attitude rather than a narrow interpretation of the biblical precept. ${ }^{8}$ Rabbinic authorities mostly allow representational art in two-dimensional media, while the restriction prevails for figurative sculpture. ${ }^{9}$ The history of Jewish art has shown that the presence or absence of figurative painting is not entirely a matter of observation of the law but owes more to acculturation. Within a Roman, Greek, or Christian environment, Jewish art was often figurative, whereas within Islamic culture ornamental decoration was the norm.

All the extant illuminated manuscripts from the Iberian Peninsula were produced within a Christian environment; no decorated books have survived from the Islamic period, although some examples from other areas of the Islamic world have come down to us. From the ninth century onward Hebrew Bibles were decorated in the Middle East and North Africa, and they reflect a similar basic attitude toward decoration; we find the carpet page, as well as depictions of the sanctuary, although the Spanish versions of the latter differ significantly in detail from the earlier Middle Eastern exemplars. ${ }^{10}$ Figurative painting did not play any role in this art.

It is the purpose of this study to characterize the two idioms, to outline the paths of acculturation they mirror, and to shed light on the potential audiences they may represent. I shall suggest that the aniconic idiom, rooted in Islamic culture, arose from the Judeo-Islamic heritage linked with the cultural values of Sephardic Jewry, ${ }^{11}$ as manifest, for example, in the worldview of Maimonides's rationalist scholarship. The narrative idiom of the biblical cycles, revealing a dialogue with Christian Old Testament imagery, is embedded in the cultural ambience of Ashkenazic Jewry ${ }^{12}$ as represented by northern French Jewish scholars and their Spanish proponents, who championed a traditional, antirationalist worldview. The two idioms present themselves as faithful reflections of the cultural transition experienced by Spanish Jewry during the thirteenth and fourteenth centuries. They evolved as a by-product of a cultural struggle that strongly affected the Spanish Jewish communities during the High Middle Ages. Displaying cultural exchanges with the non-Jewish environment, the art of Hebrew illuminated manuscripts in Spain beautifully illustrates the dynamics of acculturation in a period of cultural transition, not only within Jewry but also within the hosting culture. 


\section{Aus rechtlichen Gründen steht diese Abbildung nicht im Open Access zur Verfügung}

1 Damascus Keter, carpet page, Burgos, 1260. Jerusalem, Jewish Nat. and Univ. Lib. cod. $4^{0} 790$, fol. 310v

The first flourishing of the Spanish Hebrew Bible took place during the reigns of Fernando III (1217-52) and his successor, Alfonso X the Wise of Castile (1252-84). This period has been characterized by some scholars as conviven cia ${ }^{13}$ a period when the three coexisting cultures intensely interacted and the final phase of the transmission of ancient and new knowledge from Islam to Christian Europe. Some scholars have criticized the notion of convivencia as romanticizing the situation of the Jewish minority in coping with its Christian environment on the one hand and the Mudejar minority on the other. ${ }^{14}$ Convivencia is best understood-at least in the context of this argument-solely in terms of cultural life and cultural exchange. It was used in this sense in the 1992 catalogue of the Jewish Museum in New York entitled Convivencia, ${ }^{15}$ which brought together a rich variety of books, scientific instruments, and other objects of material culture from the three religions, pointing out the cultural interaction they mirror. This approach is apparent in the way
Thomas F. Glick redefines convivencia in his introduction to the catalogue, stressing the social dynamics it reflects. ${ }^{16}$ However, this was not only a period of convivencia, which implies an intense cultural exchange between the three religions, but also one of cultural transition and transformation: Spain changed from the western outpost of the Islamic Empire to a group of Christian kingdoms, and Spanish Christianity, previously a minority on the frontier, became part of Christian Europe. ${ }^{17}$

Thus, Spanish Jewry found itself shifted from an Islamic environment to a Christian one. ${ }^{18}$ No scholarly effort is necessary to observe that aniconic decorative patterns reflect an exchange with Islamic culture, whereas the iconographic program of the biblical picture cycles has its counterpart in the Christian world. Instead of being seen as a conclusion, this distinction could become a starting point in an investigation of how this cultural transition shaped Jewish art, what steps the transition took, and what the use of an Islamic 
Aus rechtlichen Gründen steht diese Abbildung nicht im Open Access zur Verfügung idiom meant. In former scholarship the use of Islamicizing ornament was treated simply as a matter of copying from a model and non-Jewish influence. Acculturation, meaning an adoption of Islamic fashion, lifestyle, or artistic forms, should certainly be evaluated within a much broader spectrum of cultural manifestations. Acculturation, as defined by Glick, ${ }^{19}$ does not necessarily imply social contact and proximity. Premodern mutual cultural influence and cultural borrowing are not always by-products of assimilation-which Glick thinks of as a social, rather than a cultural process-nor do they necessarily lead to it. For the Jews of Spain, acculturation to Islam was easier than to Christianity, since Islamic culture also had secular aspects more readily adopted by Jews. Jewish acculturation to Islam reached a peak during the tenth century, when Jews played an active part in Islamic society and this interaction stimulated a variety of creative activities, leading to the formation of Hispano-Jewish culture with its specific characteristics. The ornamental decoration of Spanish Hebrew Bibles is only one of the many echoes of this interaction.
2 Parma Bible, temple implements, Toledo, 1277. Parma, Bibl. Pal. ms Parm 2668, fol. 7v (photo: su concessione del Ministero per i Beni Culturali e Ambientali)

\section{Aniconism and Islamic Formal Language in Castilian Bible Decoration}

An important school of aniconic Bible decoration flourished during the thirteenth century in Toledo. An outstanding example is the so-called Marseilles Bible, ${ }^{20}$ written around the middle of the century by the scribe Isaac ben Israel ${ }^{21}$ and lavishly illuminated. As Gabrielle Sed-Rajna has shown, its unique carpet-page design of palmetto leaves within scrolls forming medallions is borrowed from architectural decoration found all over the Islamic world, including Spain, ${ }^{22}$ specifically, in architectural sculpture at the Taifa palace in Toledo. ${ }^{23}$ Closely related is the so-called Damascus Keter in Jerusalem, ${ }^{24}$ a Bible produced in 1260 in Burgos. It exhibits yet a richer decoration program, involving interlace patterns (Fig. 1). These pages are executed in a combination of painting, in gold and color, and micrography, decorations applied in minute lines of script.

Hayyim ben Israel, a relative of Isaac ben Israel, copied a Bible in Toledo in 1277 (now in Parma), ${ }^{25}$ which introduces the representation of the temple implements (Figs. 2, 3).${ }^{26}$ In 
3 Parma Bible, temple implements, fol. 8r (photo: su concessione del Ministero per i Beni Culturali e Ambientali)

\section{Aus rechtlichen Gründen steht diese Abbildung nicht im Open Access zur Verfügung}

time, this feature became one of the dominant characteristics of Sephardic Bible decoration. The manuscript presents the ark of the covenant, the altars, the seven-branched candlestick, the shewbread table, and various vessels spread out flatly on the vellum background of the page. The depiction indicates no spatial relationships whatsoever; the implements are detached from any physical environment, hovering like bodiless, golden silhouettes on the page. They do not appear as an illustration to Exodus, chapter 25, the description of the desert sanctuary, or to the Solomonic temple in 1 Kings, chapter 6 but-as numerous scholars have asserted-represent the future messianic temple. ${ }^{27}$ With the Bible itself perceived as a "minor temple," 28 the temple implements stand at the beginning of the volume as a symbol of the entire holy scripture.

The implements of the Parma Bible and their successors in other Sephardic Bibles (for example, Figs. 4, 5, 8, 9, 11) have been studied extensively by many scholars of Jewish art, who primarily discussed them in terms of iconographic models ${ }^{29}$ and biblical, as well as extrabiblical, text sources. ${ }^{30}$ Whatever models, if any, might have provided a source for the illuminator who first created this image in late thirteenth-century
Spain, its flatness of design, high degree of abstraction, complete lack of volume and perspective, and appearance with carpet pages and other forms of aniconic decoration borrowed from the repertoire of Islamic art clearly point to an Islamic cultural ambience. The decorative programs of the Bibles from Toledo and Burgos, all made almost two hundred years after the Christian conquest of Toledo, speak an explicit Islamicizing artistic language. Despite the fact that they were Christian, Toledo and Burgos certainly offer typical examples of the cultural convivencia that characterized life in Spain during this period. Following the conquest of Toledo in 1085, Spanish Christendom, for the first time, had to deal with a large Muslim population when the majority of Muslims chose not to move south into a region still governed by Muslim rulers. ${ }^{31}$ Although never under Muslim domination, Burgos, a city of major political importance in Old Castile founded by Christians in the ninth century and under Christian domination ever since, also attracted a large community of Mudejares, who specialized in certain fields of craftsmanship that were less common among Christians, primarily ceramics and architecture. ${ }^{32}$ As Teofilo Ruiz put it, their economic situation was in a "sorry 
Aus rechtlichen Gründen steht diese Abbildung nicht im Open Access zur Verfügung
4 Perpignan Bible, temple implements, Perpignan, 1299. Paris, BNF héb. 7, fol. 12v

and melancholy state." 33 Both cities also housed prominent Jewish communities. ${ }^{34}$

These large Mudejar and Jewish groups notwithstanding, both Toledo and Burgos, culturally speaking, were predominantly Christian. The churches built there were Romanesque and later Gothic; illuminated manuscripts produced during the reign of Alfonso X the Wise were mainly Gothic in character. ${ }^{35}$ Although Mudejar craftsmanship played a role in certain decorative branches and left numerous traces in some examples of architectural decoration, ${ }^{36}$ the Christian culture of Toledo or Burgos had caught up with Christian Europe after the long period of isolation during the Muslim era.

The Hebrew illuminated manuscripts discussed above, however, created in a predominantly "Gothic" artistic environment, do not simply exhibit Islamic influence that could be expected as a result of the presence of Mudejar culture in their immediate environment, they show a clear preference for the Islamic artistic idiom. The same is true, as Jerrilyn Dodds has shown, of the synagogues of Toledo erected during the thirteenth and fourteenth centuries. ${ }^{37}$ Dodds links the design of these buildings to the Jews' familiarity with the literary and scholarly culture of Islam. The design of the Ibn Shoshan synagogue, for instance, is to be regarded, Dodds thinks, as an expression of the Islamic-Jewish cultural symbiosis of the past. The Jews spoke an Islamic cultural language, and in giving their cultural idiom a material expression, they
Aus rechtlichen Gründen steht diese Abbildung nicht im Open Access zur Verfügung relied on contemporary Islamic art for inspiration. At the same time, Mudejar-style architectural decoration had permeated fashion and taste, becoming widely used in Christian secular architecture. As no Mudejar manuscript has survived, it appears that decorated Mudejar manuscripts either were not fashionable or did not exist at all. Manuscript decoration was practiced by Muslims elsewhere in Spain, and examples are extant, primarily from Valencia and Granada. ${ }^{38}$ In this art, the geometric carpet page played an important role, and latèr carpet pages in Hebrew Bibles share most of their features with contemporary Muslim specimens, as will be discussed below. Yet this is not true for those of the ToledoBurgos group. Nor do they appear to derive from earlier manuscript sources. While some carpet pages of MiddleEastern Hebrew manuscripts display a technique of micrographic lines combined with colored fillings similar to carpet pages of the Marseilles Bible and the Damascus Keter, they differ in character. ${ }^{39}$ The latter present a unique design, borrowed from architectural decoration, found in Toledo, among other cities. ${ }^{40}$

Aniconism, Islamic Form, and the Encounter with Gothic Style: Catalonia

In 1299, the Parma Bible from Toledo probably served as model for a specimen produced in Perpignan. The manuscript, preserved in Paris, ${ }^{41}$ was written by a certain Solomon ben Raphael, who, according to Joseph Gutmann, may have been the illuminator as well. ${ }^{42}$ The composition of the tem- 
ple implements (Figs. 4,5) closely follows the earlier Toledan example (Figs. 2, 3), except that the framing calligraphic inscription is different and some vessels were added in the Perpignan Bible, probably due to its larger format. The rest of the program also reveals some relationship. Both books contain micrographic carpet pages. One of those in the Perpignan Bible (Fig. 6) has a near relative in the Parma Bible (Fig. 7), a further indication that the latter served as a model. ${ }^{43}$ Other features of the decoration betray some slight impact of Gothic style for the first time: the tables at the beginning of the book containing the Masoretic differences are adorned with Gothic pointed arches (fol. $2 \mathrm{v}$ ), whereas the Parma example lacks this kind of design. Two years later, in 1301, the same temple image was adopted for a second time, for a Bible now kept in Copenhagen. ${ }^{44}$ The provenance is no longer legible in the colophon. This manuscript was also probably produced in Perpignan, or some other place in Roussillon. The design of the implements in the latter Bible (Figs. 8,9) and the composition as a whole show much in common with the Toledan predecessor, although the red and blue diapered background reveals the influence of Gothic decorative practice. As in the preceding examples, the Copenhagen volume also contains micrographic carpets of a simple geometric design (fols. 10v, 11r) that greatly resemble parallels in the Perpignan Bible. The tables with the Masoretic differences are ornamented by a painted design of Gothic pointed arches and floral patterns (Fig. 10).

After having been enriched with some Gothic features in Perpignan, the decoration seen in the Castilian Hebrew Bibles, including the representations of the temple implements in most examples, carpet pages in some, and a variety of other decorative elements, reappears frequently in the various regions within the Crown of Aragon, especially in Catalonia and Roussillon, throughout the entire fourteenth century. Since many of the manuscripts of this group have been described, analyzed, categorized, dated, and localized in earlier research, ${ }^{45}$ I shall refrain from a detailed presentation, instead limiting myself to a short discussion of some of the most relevant features.

What these Catalan manuscripts have in common is a preference for forms borrowed from an Islamic repertoire, a feature already familiar from Castilian Bibles. As foreshadowed in the Bible from Perpignan and the manuscripts related to it, this formal language is combined with other features inspired by Gothic miniature painting. The latter, however, plays a secondary role in the overall artistic language. As in the Copenhagen Bible (Figs. 8, 9), many of the temple depictions of the later Catalan manuscripts exhibit a typical Gothic diapered, checkered, or foliated background (Fig. 11). The basic design of the carpet pages, on the other hand, usually follows Islamic interlace patterns, often in the form of central stars. The most striking example appears in the so-called Farhi Bible, ${ }^{46}$ written between 1366 and 1382 by Elisha ben Abraham Benvenisti Crescas, most likely in Provence. ${ }^{47}$ It possesses no fewer than twenty-nine carpets (Fig. 12). This particular type of dense star interlace design was very common in late Islamic manuscript painting in the Iberian Peninsula, of which various examples survive, mostly made in Valencia and Granada during the Almohad and the Nasrid periods, such as a Qur'an written in 1304, probably in
Granada (preserved in Paris, Fig. 13) ${ }^{48}$ A Qur'an of 1326 from the Maghreb shows carpet pages of a very similar composition. ${ }^{49}$ The design of the Farhi Bible is enriched by Gothic floral motifs protruding from the corners of the carpet design. ${ }^{50}$

The Foa Bible, kept in the library of the Compagnie des Prêtres of St-Sulpice in Paris, ${ }^{51}$ is another example of this combination of styles. Besides the mixture of motifs in the temple depiction and the carpet pages, it contains numerous floral scroll designs in the margins of the text. ${ }^{52}$ Many Catalan Bibles have decorated tables at the beginning with the Masoretic lists, the precepts, calendars, or other material. Following the above-mentioned example in Copenhagen (Fig. 10), the later Catalan Bibles also exhibit Gothic pointed arches and mostly Western decorative embellishments in the spandrels. $^{53}$

The Catalonian Hebrew Bible thus not only revives the decoration program rooted in an Islamic cultural ambience but also echoes-in some cases slightly, in others more explicitly-the European Christian Gothic artistic environment of fourteenth-century Catalonia. Yet Islamic design and aniconism dominate this group as well. Viewed in the light of the cultural tradition of Catalonia, especially its northern parts, where Islamic culture never played the role it did in Castile, this preference for Islamic features is surprising, and its circumstances need to be elaborated further. In past research on Sephardic manuscript painting the culture of the entire peninsula has been treated uniformly as a Christian culture nourished heavily by its Islamic heritage. This attitude is misleading. In my view, the Islamic features in Catalan Jewish art cannot be judged by the same criteria as those of Castilian Jewish art. Bezalel Narkiss's recent publication on the Golden Haggadah includes a discussion of the flourishing Jewish community in "Moslem Barcelona" during the ninth, tenth, and eleventh centuries. According to Narkiss, the wealth of the fourteenth-century Barcelonan community and its roots in the Islamic past account for the luxuriousness of the Golden Haggadah. ${ }^{54}$ This notion is founded on a misconception: a Judeo-Islamic community never existed in Barcelona. The city was conquered by the Carolingians in $801,{ }^{55}$ and "Old Catalonia" had very little Islamic cultural presence, meaning a community strong and extensive enough to leave a cultural imprint on its environment and to be as influential as the Mudejar community was in Burgos, for example. Few such communities existed in the towns of northern Catalonia. It was, in fact, the Jews who were the cultural transmitters between the two worlds. Although the Jewish community of Barcelona had no Islamic history, it included among its members the descendants of immigrants from the south who had fled the Almohad persecutions of the twelfth century.

At the time the Perpignan Bible and its follower in Copenhagen were produced, the town of Perpignan in Roussillontoday in southern France-belonged to the kingdom of Mallorca, itself part of the Federation of the Crown of Aragon. Pre-Reconquest Catalonia and Roussillon had been culturally linked with France since Louis the Pious conquered Barcelona in 801 . This was the one region of the peninsula that had been part of Christian Europe from the Carolingian period, and it was much more closely associated with Christian European culture than were any of the Christian kingdoms that 
Aus rechtlichen Gründen steht diese Abbildung nicht im Open Access zur Verfügung

developed in the northwest. During the thirteenth and fourteenth centuries Catalonia still had strong links to French culture. The artistic environment of Jewish art, in whatever field or medium, was therefore that of the late Gothic style. While Mudejar art and culture were present in other parts of the Crown of Aragon, especially in the southern areas of Valencia, in northern Catalonia and Roussillon there was no such tradition. According to Philip Daileader, Perpignan never housed a Muslim community. ${ }^{56}$ This is true also of northern Catalonia. ${ }^{57}$ In a few towns only is there evidence of 
7 Parma Bible, micrographic carpet page, fol. $9 \mathrm{v}$ (photo: su concessione del Ministero per i Beni Culturali e Ambientali)

\section{Aus rechtlichen Gründen steht diese Abbildung nicht im Open Access zur Verfügung}

a small Muslim population. Gerona, for example, can account for one Mudejar household. ${ }^{58}$ Only Barcelona, apparently because it was an economic center, had a larger Mudejar population, ${ }^{59}$

It is all the more puzzling, therefore, that within this Western European Christian Gothic cultural ambience the Islamic artistic idiom enjoyed a strong revival in the decoration of Hebrew Bibles. This has been explained hitherto simply in terms of an earlier artistic tradition transmitted from the Middle East via Castile to fourteenth-century Catalonia, or of the presence of Islamic culture on the peninsula in general. However, the cultural past of the Catalan heartland and Languedoc was linked to Christian France rather than to Muslim Spain. Links with the Islamic world occurred only after the union with Aragon and the conquest of Saragossa, Huesca (in the early twelfth century), Mallorca, and Valencia (during the first half of the thirteenth century).

Channels for the transmission of Islamic influence in fourteenth-century Catalonia did exist, whether through the descendants of Jewish immigrants from the south, Mudejar communities in the conquered areas of Saragossa and Valencia, or various contacts Jewish Catalan travelers might have been able to establish (Jewish diplomats from Catalonia were sent on missions to the Muslim world) ${ }^{60}$ Although Catalan trade in general-and Jewish international trade in particular-was in decline during the fourteenth century, we do know of Catalan Jewish merchants who traded with the Maghreb, while other branches of commerce to other parts of the Muslim world became less and less available to Jews due to an increase in Christian activity during the High and late Middle Ages. ${ }^{61}$

Opportunities for Islamic influence thus existed. Yet, given that the artistic environment was entirely linked to Gothic Europe, the dominance of the Islamic idiom in the Hebrew Bibles is striking. Commerce is not a sufficient explanation here, and it should be stressed that trade connections between Christian merchants and the Middle East did not mean that Islamic culture had an impact on Christian Catalan art to the degree (if at all) that it had on Jewish art, or to the degree that Italian mercantile exchanges had on Christian Catalan culture ${ }^{62}$ Neither can the dominance of Islamicizing forms be explained simply in terms of the continuation of a Castilian tradition, since no clear evidence of Castilian influence is 
Aus rechtlichen Gründen steht diese Abbildung nicht im Open Access zur Verfügung

apparent in Catalan Bibles. The Catalan Bibles greatly develop the iconography of the temple implements beyond that seen in Castilian opening pages, and the carpet-page designs, with their peculiar mixture of styles and their dependence on late medieval Islamic parallels, are different in most details. In specific patterns, none of the Catalan manuscripts follows any of the known Castilian predecessors. Thus, the Catalan Bibles are an interesting manifestation of merged styles. Islamic features remain prominent. Although the concept of convivencia cannot be applied to Catalan culture, the design of the Bibles produced in this area nevertheless reflects Jewish-Islamic cultural interaction and therefore has evoked associations with convivencia. This evocation, however, has misled earlier scholarship.
8 Bible, temple implements, Roussillon, 1301. Copenhagen, Roy. Lib. heb. II, fol. 11v
The Impact of Christian Art on Narrative Painting

The aniconic idiom of the Bible manuscripts, all displaying various degrees of affinity with Islamic forms, contrasts strongly with the narrative character of the biblical picture cycles in some of the Passover Haggadot. A further puzzle is the fact that the group of Haggadot under discussion exhibits an illustration program completely unrelated to the text. The text of the Haggadah, containing the narrative of the Exodus of the Israelites from Egypt, offers plenty of opportunity for visualization. It includes a variety of biblical themes specifically related to the Passover feast, but these do not necessarily figure in the biblical cycles of our group. In Central Europe the highly narrative character of this text gave rise to rich iconographic programs closely linked to the text portions 
9 Bible, temple implements, Copenhagen, Roy. Lib. heb. II, fol. 12r

\section{Aus rechtlichen Gründen steht diese Abbildung nicht im Open Access zur Verfügung}

they accompany, inserted on the margins of the relevant pages. ${ }^{63}$ Some Sephardic specimens likewise depict events specifically indicated in the Haggadah; these appear-as in Central Europe and in Italy-on the margins of the text. ${ }^{64}$ Other of the decorated Haggadot adopt an aniconic approach, although in a Gothic style; they may perhaps reflect a cultural background similar to that of the Bible manuscripts under discussion. ${ }^{65}$

None of the approaches was used in the group I shall refer to in the following paragraphs. The most outstanding artistic component of these manuscripts is an elaborate biblical cycle, covering - with some variations in length, detail, and selection of scenes-the narrative in the books of Genesis and Exodus. While the miniatures appear at the beginning of the Haggadah, preceding the text, or at the end, no attempt whatsoever is made to link their imagery to the actual text.
The main concern of the cycles is not the Haggadah or the particular event of the departure from Egypt, but biblical history in general.

Most of the surviving examples were made in the fourteenth century, and scholars believe them to be of Catalan provenance. ${ }^{66}$ An early manuscript, ms Or. 2737 in the British Library, however, was most likely produced in late thirteenth-century Castile. ${ }^{67}$ The most extensive cycle of the group is found in the Sarajevo Haggadah, ${ }^{68}$ which opens with a series of Creation scenes and concludes with events picturing the Israelites in the wilderness on their way to the promised land. The Golden Haggadah in London (Fig. 14) ${ }^{69}$ and a related cycle likewise preserved in the British Library (ms Or. 2884, Fig. 16) ${ }^{70}$ also include events from Genesis and Exodus. Others, such as the Rylands Haggadah in Manchester $^{71}$ and another example in London, ${ }^{72}$ a close relative to 
Aus rechtlichen Gründen steht diese Abbildung nicht im Open Access zur Verfügung the former, limit themselves to the Book of Exodus. The iconography of these cycles raises many questions, especially concerning their pictorial sources, and has been the subject of numerous scholarly discussions. ${ }^{73}$ As I have shown elsewhere, I assume the pictorial sources to be primarily of contemporary Christian origin. ${ }^{74}$ However, the cycles underwent significant changes in the process of translating the Christian sources into a recognizably Jewish pictorial language. As part of this process, the imagery was augmented by extrabiblical interpolations, ${ }^{75}$ which played a major role. This material is based on a particular branch of biblical exegesis known as Midrash, which enriches the biblical account with explanatory legendary material, often comprising entire additional independent narratives. It can also be shown that Jewish polemical writings of the High and late Middle Ages guided the composers of the programs in dealing with the
10 Bible, Masoretic lists, Copenhagen, Roy. Lib. heb. II, fol. $9 \mathrm{r}$ Christological and typological content of their Christian
models. ${ }^{76}$

One example of many ${ }^{77}$ will suffice to elucidate this point: the Golden Haggadah ${ }^{78}$ includes a unique depiction of Jacob's dream of the heavenly ladder (Gen. 28:10-15), on a page with three other illustrations (Fig. 14). In a style typical of Gothic Christian art, with close Christian counterparts in contemporary Catalan book art, ${ }^{79}$ it shows the patriarch lying at the foot of the ladder, while two angels, who have stepped down from it contemplate him. An angel on the ladder steps up to a windowlike hole in the sky, in which the face of another angel can be seen. According to the late antique Aramaic Targumim, which elaborate the biblical narrative, ${ }^{80}$ the two angels who went to Sodom were expelled from the heavenly realm for having revealed the secrets of the Lord of the World. They wandered on earth until Jacob left his 
11 Sephardic Duke of Sussex Bible, temple implements, Catalonia, ca. 1350. London, Brit. Lib. ms Harley 15250 , vol. $4 \mathrm{r}$

\section{Aus rechtlichen Gründen steht diese Abbildung nicht im Open Access zur Verfügung}

father's house, when they accompanied him to Bethel. On the night of the dream, they climbed the ladder and summoned their fellow angels to see the righteous patriarch. The other angels then came down and contemplated Jacob. The miniature seems to show the contemplating angels on the ground, with one of the exiled angels calling to the others in Heaven. The "window" in the sky recalls Christian depictions of this scene from the High and late Middle Ages, where the bust of an anthropomorphic figure of the Lord appears in a similar opening, ${ }^{81}$ however, this common iconographic type is transformed to reflect a Jewish tradition.

Thus, these cycles draw on contemporary Christian art on the one hand, but reflect a specifically Jewish understanding of the biblical narrative on the other. This is true also for Or. 2737. Although labeled by Bezalel Narkiss the "HispanoMoresque Haggadah," 82 its style, which is based on earlier Spanish stylistic sources, is by no means "Moresque." It is indebted to the court style of Alfonso $\mathrm{X}$ the Wise in late thirteenth-century Toledo, ${ }^{83}$ which is Gothic, and some of its features-especially in the ornamentation-are rooted in the arts of the early medieval Christian kingdoms. This pictorial language, partly innovative, partly based on the Visigothic tradition, was actually opposed to Islamic culture rather than an offspring of it. While Islamic characteristics exist in the early medieval art of Spain, they are comparatively rare. ${ }^{84}$ In our present context, this style indicates a set of characteristics that developed in Spanish Christian art prior to Spain's cultural links with Romanesque and Gothic Europe. In the context of Hebrew manuscript painting in the peninsula, the overall artistic language of Or. 2737, as of the other figurative Haggadah cycles, is that associated with iconographic influences from Christian art and Midrashic exegesis.

To conclude this short survey of Hebrew manuscript painting in Spain: in terms of artistic borrowings the Toledan Bibles are faithful to Islamic art in both ornamental pattern and aniconism. The Catalan Bibles preserve the aniconic attitude and combine Islamicizing forms with Gothic features, whereas in some specific manuscripts there is still a clear preference for an Islamic formal language. The figurative biblical picture cycles, on the other hand, borrow almost exclusively from Christian art and do so in both stylistic and iconographic respects, their imagery being translated 
Aus rechtlichen Gründen steht diese Abbildung nicht im Open Access zur Verfügung
12 Farhi Bible, carpet page, Provence?, 1366-82. Sassoon coll. ms 368, p. 43 (photo: R. David Sassoon, Jerusalem)

through Midrashic interpolations into a Jewish cultural idiom. In what follows I shall try to examine the two idioms in the light of the different facets of Sephardic culture during the thirteenth and fourteenth centuries.

\section{The Cultural Climate within Late Medieval Spanish Jewry}

The phenomenon of two such different artistic idioms coexisting side by side in Sephardic book art reveals very divergent patterns of acculturation, to Islam on the one hand, to Christianity on the other. Acculturation to Islam had been a continuous process ever since the Judeo-Islamic cultural symbiosis developed in the early Middle Ages; it survived to some extent the Almohad persecutions, somehow stabilized during the period of convivencia, and in the fourteenth century remained an important element in the cultural life of some circles. The borrowings from Christian art, on the other hand, reflect some degree of acculturation to Christianity, as well as significant efforts to cope with the Christian content of these borrowings. To come to grips with this coexistence of such strikingly different-and clearly separated-expressions of acculturation, the climate of late medieval Spanish Jewry needs to be illuminated. In the following I shall place an emphasis on the audience of the Islamicizing Bible, whereas that of the biblical picture cycles will be discussed in detail elsewhere. ${ }^{85}$ The audience of the Sephardic Bibles, as will be proposed below, should be looked for in the cultural climate of those Jews who represent the values of Judeo-Arabic cul- ture, as opposed to others who break with this tradition and, instead, are open to Ashkenazic influence.

Both Spanish Christian and Spanish Jewish culture of the thirteenth and fourteenth centuries underwent a process of transition from Muslim to Christian domination, not only on the political but also on a cultural level. Whereas political rule could change within a few days on the battlefield, cultural transition was a century-long process. The Islamic-Jewish cultural symbiosis had brought forth generations of scholars whose cultural background differed in many respects from that of the Talmudic sages of the past; it differed even more significantly from that of contemporary Ashkenazic scholars. A group of rational Jewish philosophers joined the stream of Muslim thinkers of the Middle Ages. They represented certain cultural values that were not in contradiction with the Halakhic tradition of the Talmudic period-the tradition of religious law-but were very different from other religious values of the past. The biblical exegesis of late antiquity was dominated by the Midrashic method; that of early medieval Spain was guided primarily by linguistic and philological thinking, a method represented, for example, by Abraham ibn Ezra. Other scholars interpreted biblical narratives as well as Midrashic narratives of the Talmudic era allegorically or metaphorically.

The resulting cultural climate, associated with a certain set of social and intellectual values, reached a climax in the scholarship of the most outstanding medieval Jewish thinker, Moses ben Maimon, commonly known as Maimonides, who died in 1204. The cultural values of Maimonides-philosophical rationalism and scientific thinking combined with Halakhah (the religious law) -were closely linked to the IslamicJewish symbiosis. The educated Jew in this cultural at-

Aus rechtlichen Gründen steht diese Abbildung nicht im Open Access zur Verfügung

13 Qur'an, carpet page, Granada? 1304. Paris, BNF arabe 385, fol. $130 \mathrm{r}$ 
Aus rechtlichen Gründen steht diese Abbildung nicht im Open Access zur Verfügung

14 Golden Haggadah, Jacob's ladder, Catalonia, ca. 1320. London, Brit. Lib. ms Add. 27210, fol. 4v

mosphere was fluent in Arabic, participated in Islamic culture, and was active in the transmission of ancient and Islamic knowledge to Christian Europe. The writings of Maimonides began to circulate during the later decades of the twelfth century. They spread quickly and were widely read among Spanish Jews, the majority of whom were living under Christian rule by the time of Maimonides's death. Besides philosophical treatises, Maimonides also wrote a Halakhic codex 
known as the Mishne Torah, which organized the Halakhic material according to themes, an innovation in Halakhic teaching whose way was prepared by the earlier Halakhist Isaac ben Jacob Alfasi. Henceforth, Halakhah would not necessarily mean painstaking Talmudic research but instead could be the study of a well-organized and structured legal codex. Maimonides's interpretation of the Halakhah was also strictly determined by his rationalist worldview. One example-out of many-is his discussion of the mezuzah, a small capsule attached to the doorposts of Jewish homes containing a piece of vellum with verses from the Book of Deuteronomy. His attack on the popular superstitious practice of turning the mezuzah into an amulet is particularly sharp. ${ }^{86}$

With Maimonides Sephardic culture reached its ultimate peak. His thought and the cultural values associated with it were the fruit of Islamic-Jewish coexistence in Muslim Spain. If we bear this in mind, the Islamic artistic idiom of the Hebrew Bibles appears as an expression of that worldview. However, by the end of Maimonides's life this culture had begun to wane. Moreover, shortly after his death in 1204, this worldview became a matter of controversy. ${ }^{87}$ Rationalism was considered by some a danger to traditional Jewish values, the allegorical interpretation of the Midrashim of the Talmudic sages a threat to their authority. Some opponents believed even Maimonides's Halakhic compilation would lead to the neglect of Talmudic studies, although the majority of scholars accepted it as authoritative. A cultural struggle developed between rationalists and their opponents and reached a climax in 1232, when Maimonidean writings were burned by the Church.

The precise circumstances of this event and the role Jewish antirationalists perhaps played in it are not entirely clear. ${ }^{88}$ The burning of the books was preceded by mutual rabbinic excommunication by Maimonidean and anti-Maimonidean scholars. The controversy had been initiated by Solomon of Montpellier and his student Jonah Gerundi. Moses ben Nahman of Gerona, known as Nahmanides, who ideologically supported the antirationalist side, tried to pursue a moderate policy of compromise. Among the prominent rationalists were figures such as Judah Alharizi-no longer alive at the time of the actual bans of 1232-and Sheshet Benvenisti of Barcelona. The Maimonidean worldview has been adopted by the Jewish elite, of which many a member belonged to the rich and large community of Toledo. The controversy did not end in 1232, and its continuation during the following eighty years left a strong mark on Spanish and Provençal Jewish culture, with far-reaching consequences. For a few decades the rationalist worldview remained the more dominant in Spanish Jewry, but it was strongly rivaled and challenged by an antirationalist movement supported and nurtured by northern French Ashkenazic scholarship, whose representatives-known as the tosafists-stood for traditional Talmudic study, an antirationalistic worldview, and an uncritical acceptance of the authority of Talmudic Midrash. Allegorical and metaphorical interpretation of the Midrash and especially of the Bible itself was vehemently refuted, the philosophical approach was not pursued. It should be stressed, however, that the acceptance of Talmudic Halakhah was never an issue.

The division between rationalists and antirationalists sur- vived the actual Maimonidean controversy of the 1230s. During the later thirteenth and the early fourteenth centuries the split took the form of those who accepted non-Jewish, Greek philosophy, linked with a tendency to preserve the JudeoIslamic heritage, versus those who rejected alien thought, linked with an ever growing detachment from Judeo-Islamic culture. By the time these attitudes had crystallized in the early years of the fourteenth century, the authority of Maimonides's writings was unquestioned. What remained in dispute were some of the issues the original controversy had brought to scholarly consciousness. In 1303, when the Provençal scholar Abba Mari of Lunel decided that philosophical study was being carried to extremes among other Provençal thinkers, he urged the supreme Halakhic authority of his generation, Solomon ibn Adret of Barcelona, to ban the study of Greek philosophy for those under the age of twentyfive. ${ }^{89}$ One of the most urgent concerns at this stage was the allegorical interpretation of the Bible, as practiced by some of the Provençal philosophers. A second ban was therefore proclaimed, at the same date, against scholars teaching extreme allegorical interpretation. ${ }^{90}$

Concern for the authority of the late antique Midrash, put at risk by rationalist, allegorical, and metaphorical approaches, led to its revival and the proliferation of new Midrashic writings and compilations. Another issue that began to dominate the cultural realm of Jewish thought was the Kabbalistic worldview growing from the seeds of antirationalism. ${ }^{91}$ The Book of Zohar, the central work of Kabbalah, was composed during the 1280s by Moses de Leon, who lived in Avila. Its wealth of Midrashic material places the Zohar directly within the scope of the revival of Midrashic exegesis. $^{92}$

Looking at the Hebrew Bibles and the Islamic artistic idiom of their decoration programs in the light of these developments, it becomes clear that they should be associated with those circles that aimed at maintaining and preserving the Islamic cultural heritage. The biblical cycles in the Haggadah manuscripts, on the other hand, with the frequent Midrashic interpolations in their iconography, reflect the world of the Ashkenazic tosafists and the revival of Midrashic commentary. These links can be elucidated with further argumentation. In the Bibles, besides the Islamic decorative style, the iconography of the temple depictions creates a further connection. Carl Otto Nordström analyzed some relevant written sources and concluded that beyond the biblical texts in Exodus and 1 Kings that inspired the compositions, they were designed after extrabiblical material. ${ }^{93}$ Recently Elisabeth Revel-Neher has discussed the pages and their iconographic sources in a wider context of Jewish and Christian art. ${ }^{94} \mathrm{I}$ have shown elsewhere that it was book 8 of Maimonides's Mishne Torah in particular that had a major impact on the way the implements were visualized. ${ }^{95}$ Moreover, it can be seen that the shape of the stepped altar of sacrifice and its ramp in the temple images (Figs. 3, 5, 9) was borrowed from drawings that accompany manuscripts of Maimonides's texts on the temple in his commentary to the Mishna and in book 8 of the Mishne Torah. It can be compared, for example, to a drawing in a copy of the Mishna commentary from the twelfth or the early thirteenth century written probably-as some scholars claim $^{96}$ - by Maimonides himself (Fig. 15) ${ }^{97}$ In short, draw- 
ings in Maimonidean texts, like the texts themselves, served as a major source of inspiration, certainly to a greater degree than any of the potential visual sources proposed in previous research. ${ }^{98}$

The decoration program typical of the workshops of Toledo and Burgos evolved-so it would seem-precisely during the decades following the first phase of the controversy. The earliest extant decorated Bible was signed in $1232 .{ }^{99}$ The following decades saw the blossoming of this creative activity. The presence of large Mudejar communities in both Toledo and Burgos and the survival of Islamic culture in Toledo supplied a whole range of stimulating models. Catalan Bible decoration developed under different circumstances. Its sources were apparently in Perpignan, a town dominated by Christian culture for centuries. When the Toledan decoration program was adopted in Perpignan in 1299, it might have been affected by the contemporary tensions in the cultural climate that led to Abba Mari's activity in 1303 and the resulting ban in 1305 . The roots of this phase of the conflict over philosophical study lie in Provence and Languedoc, where the earliest decorated Bible of this group can be traced. During these years the community of Perpignan was led by one of the key rationalist figures of the second phase of the controversy, Menahem Hameiri. We know that it was this same scholar who praised the Toledan scribe Israel ben Isaac (ben Israel), declaring that his work was most accurate. ${ }^{100}$ Israel was a relative of Isaac ben Israel, the scribe of the Marseilles Bible, and of Hayyim ben Israel, of the Parma Bible of 1277, whose temple image was copied in Perpignan in 1299. We should not be surprised, then, that about 1300 , in a town whose artistic and cultural life had been. linked for centuries with Christian Europe rather than with Muslim Spain-and despite these links-a decorative style developed more than twenty years earlier in Toledo was adopted and further enriched. ${ }^{101}$ As Hameiri's remark about Israel ben Isaac shows, Toledan Bibles were available and treasured in early fourteenth-century Perpignan. Within this environment-Christian for five centuries-it is likely that those intellectual groups that had a strong interest in rational philosophy were also linked to the Judeo-Islamic heritage, and were therefore also open to influences from Islamic art. The earlier Castilian Bibles were but one of the sources the Catalan exemplars relied on. When it came to specific decorative patterns- of the later carpet pages, for examplecontemporary Islamic art played the major role. Islamic influences could have been provided by Mudejar communities in Huesca, Saragossa, or Valencia, or by trade connections between Catalan Jews and the Maghreb. However, such models were not found in the immediate neighborhood. The lack of "next-door" Islamic models underlies the mixture of Islamic and Gothic forms in the Catalan Bibles.

The narrative picture cycles of the Haggadot tell quite a different story. Their Midrashic elements were noted above. One of the methods of Jewish biblical commentary common in medieval Spain was guided by the linguistic-philological approach, practiced by scholars such as Abraham ibn Ezra, who were associated with Judeo-Islamic culture. Another way to deal with biblical commentary was the allegorical method associated with Maimonidean teaching. Neither method left any imprint on the extrabiblical material associated with the
Aus rechtlichen Gründen steht diese Abbildung nicht im Open Access zur Verfügung

15 Temple plan from Maimonides, Commentary of the Mishna, Spain or Egypt, ca. 1180. Oxford, Bodl. Lib. ms Poc. 295, fol. 295r

pictorial cycles under discussion. As shown above and demonstrated exhaustively in previous research, ${ }^{102}$ this material belongs to the world of traditional Judaism and its values. It faithfully mirrors traditional Midrashic exegesis, authoritative and untouched, that flourished among the leading antagonists of rationalist thought. The main sources of influence for these scholars were the tosafists of northern France, who strictly followed the conservative scholarly methods associated with the eleventh-century French sage Solomon ben Isaac, known as Rashi. Their methods and teaching played a major role in the Maimonidean controversy and the cultural struggle that it generated. Anxious that the authority of the Talmudic sages might be endangered and alarmed by the potential damage a rationalist worldview could cause to the values of traditional teaching, the Sephardic proponents of the tosafists safeguarded traditional study and the Midrashic method. The cultural struggle was not merely waged around a rationalist versus antirationalist worldview but ended up by pitting Sephardic Jewry against Ashkenazic, a Jewry preserving the heritage of the Islamic-Jewish symbiosis against one that evolved in a European Christian environment.

If we now approach these cycles from the point of view of the Midrashic revival, the picture becomes clearer. Among the scholars associated with anti-Maimonidean ideology and 
Aus rechtlichen Gründen steht diese Abbildung nicht im Open Access zur Verfügung
16 Passover Haggadah, Joseph hosting his brothers, Catalonia, 14th century. London, Brit. Lib. ms Or. 2884, fol. 9v practicing the Midrashic method was Nahmanides, who, although calling for moderation during the actual events arising from the controversy, admired Rashi and in matters of scholarship stood clearly on the side of the antirationalists. ${ }^{103}$ An important figure in this context was the late thirteenthcentury scholar Bahye ben Asher of Saragossa, who combined all the methods common in Spanish scholarship, but in giving a clear preference to the Kabbalistic direction, largely opposed the rationalist worldview. ${ }^{104} \mathrm{He}$ was a preacher in Saragossa and a disciple of Solomon ibn Adret. Bahye had a thorough knowledge of and a broad interest in the Midrashic narratives associated with the Bible. In short, it is the spirit of the Talmudic sages and of Rashi, the tosafists, and their Spanish followers that dominates the imagery of the pictorial cycles of the Spanish Passover Haggadot.

I shall discuss a further example from the Haggadot picture cycles in support of this argument. A depiction from London Or. 2884 shows Joseph hosting his brothers after their arrival in Egypt (Fig. 16, at lower right). According to the story in Genesis (43:31-34) Joseph had not yet revealed his identity to his brothers. At the banquet, he arranged that the brothers be seated according to their mothers and their ages. The Bible says nothing about the brothers wondering how he knew all this. Late antique Midrashim explain that Joseph pretended to read their identity with the aid of a goblet, which figures prominently in the image. ${ }^{105}$ The same interpretation recurs frequently in all the sources that must have played a role in the revival of the Midrash in Spain. Rashi himself, the supreme authority for antirationalist scholars, refers to it. ${ }^{106}$ Later it is found in Ashkenazic Midrashim collections, such as the thirteenth-century "Yalkut Shimoni," ${ }^{107}$ a book known to have circulated in Spain and been used in the fifteenth century by Isaac Abrabanel for his Bible commentary. ${ }^{108}$ The story is also told by Bahye ben Asher. ${ }^{109}$

A reexamination of all the Haggadah cycles reveals that these two texts-Yalkut Shimoni and the commentary of 
Bahye ben Asher-are the most dominant sources for the Midrashic interpolations. All the Midrashic elements occurring in the cycles can be found in either of them ormostly-in both. Many of them were mentioned earlier also by Rashi.

The affinity for Islamic art over borrowings from Gothic art can also be considered in terms of the attitudes of Spanish Jews toward Islam. These approach Islam as a political power-ranging from tolerant to hostile-as a hosting society, as a competing minority under Christian rule, and as a religion. Clear statements from the early days of Al-Andalus are rare, but the degree of acculturation, the cultural symbiosis of the two religions, and the familiarity of Jews with Islamic culture, its lifestyle, and the Arabic language may speak for themselves. Scholars have warned us away from the romantic notion of a golden age, ${ }^{110}$ yet Islam was generally sufficiently tolerant to stimulate a comparatively high degree of acculturation. The Almohad persecutions during the late twelfth and the early thirteenth centuries shook Jewish-Islamic relationships severely. In this situation Maimonides made a strong anti-Islamic statement, communicating the thought that Christian rule might be preferable. ${ }^{111}$ This statement has often been quoted by scholars who claim that Jews always suffered under Islam. Mark Cohen, however, made it clear that Maimonides's statement must be viewed in its specific context, the Almohad persecution, and does not refer to all aspects of Islamic-Jewish interaction. ${ }^{112}$

When the shock of the Almohad persecution had ebbed, and Jewish and Islamic communities became minorities under Christian rule, the two sometimes competed, at other times cooperated. During the late thirteenth, the fourteenth, and the fifteenth centuries Jewish attitudes toward Islam-as culture, society, or religion-could differ widely. Many Jewish utterances compared Islamic and Christian rules, and the comparison often was between bad and worse rather than between good and bad. ${ }^{113}$ Jewish statements about Islam range from positive, to ambivalent and indecisive, to negative and highly critical. ${ }^{114}$ Negative attitudes toward Islam usually arose from an antirationalistic or Kabbalistic state of mind, dominated by the fear of the potential damage of acculturation to Islam. (Acculturation to Christianity never played a comparative role in Jewish society and did not cause similar anxieties.) Among these negative pronouncements is one by Bahye ben Asher, ${ }^{115}$ mentioned above in the context of the Midrashic revival and its impact on the narrative cycles. A particularly defamatory statement was made by the fourteenth-century Kabbalist Joseph ben Shalom Ashkenazi. ${ }^{116}$ Such attitudes were due to a lack of familiarity with Islamic culture and to anxieties that Islamic cultural influence would endanger the bulwarks of traditional Judaism.

The more positive statements were composed by personalities with a strong interest in maintaining the social status and the cultural values of the old Sephardic elite, ${ }^{117}$ a social group that felt closer to the heritage of the Judeo-Islamic symbiosis than to Kabbalah or other facets of antirationalism. This social differentiation deserves more attention. Much has been said about the Jewish elite in Islamic Spain. ${ }^{118}$ Culturally, this elite was one of the most remarkable expressions of Judeo-Islamic symbiosis and acculturation to Islam. In thirteenth-century Christian Spain when the controversy over philosophy erupted, this class was still powerful in many respects. While the controversy primarily affected scholars, the majority of members of the social elite (some of them engaged in scholarship themselves) held a rationalist worldview. Moreover, the philosophers themselves created an aura of intellectual elitism, ${ }^{119}$ giving the Kabbalists the basis for attacking them on social issues. ${ }^{120}$ Subsequently, economic decline, competition from Christian courtiers, and social tensions prevalent since the late thirteenth century caused farreaching shifts in the stratification of Jewish society. ${ }^{121}$ While the old Sephardic elite, with its Judeo-Islamic cultural values, waned, a new strong, educated middle class evolved, and the two coexisted, competing with each other. Whether the decoration program of the Haggadot may have its roots in the intellectual background of this rising new middle class, less well defined than the old elite, cannot yet be determined and should be the subject of a separate study. For this study, it is significant that positive attitudes toward Islamic culture are associated with a social class that represented the cultural and social values of Judeo-Islamic culture. For these circles, the choice of an Islamic artistic language as a source of inspiration is not surprising.

Notwithstanding this assumption of the two artistic idioms as representing different cultural backgrounds, I would be rather cautious in interpreting them as statements in an ideological sense. They may be viewed as manifestations of specific cultural and social identities, growing from different cultural soils. The Islamicizing ornamental decoration of the Bibles was associated with the Sephardic Jewish elite and Judeo-Islamic scholarship. Not that a Judeo-Islamic background was always entirely congruent with a rational worldview: some of the critics of Maimonidean philosophy can be found among members of the Sephardic elite, a prominent example being Meir Halevi Abulafia in the early thirteenth century. ${ }^{122}$ Later scholars of the same Judeo-Islamic background, notably, Abraham Abulafia from Saragossa (12401291), engaged in Kabbalah, a clear manifestation of an antirationalist worldview. ${ }^{123}$ During this period, Sephardic Jewry experienced a period of transition from Islamic culture and its norms to a European one. This transition also opened a channel for Ashkenazic influence on Spanish Jewish culture, in particular that of the tosafists. It should be emphasized that the rationalists, and especially their opponents, were not always clearly defined by a complete set of cultural, social, or ideological parameters, and the transition was a long and complex process. What is of importance in the context of the Spanish Hebrew Bibles is the fact that there were varying degrees of affinity with Islamic culture. Rationalist scholarship, the cultural identity of many members of the old Sephardic elite, and the decoration program of the Bibles under discussion are among manifestations of a high degree of affinity, and they may as well be linked together. The patrons who ordered Bibles with an entirely antifigurative decoration program executed mostly in a typically Islamic artistic language tended to come from the Sephardic elite that for hundreds of years was nurtured by the JudeoIslamic symbiosis. The patrons of the Haggadot with biblical cycles were most likely to be associated with different cultural values, in which the Judeo-Islamic heritage did not play the role it did among the patrons of the aniconic Bibles. The 


\author{
Aus rechtlichen Gründen steht diese Abbildung nicht \\ im Open Access zur Verfügung
}

17 Bible, calendar, Tudela, 1300. Paris, BNF héb. 20, fol. 8r pictorial cycles visualize what biblical narrative and biblical exegesis meant in antirationalist circles. Their evolution as part of the decoration program of the Haggadot-a new type of book that developed after 1300-may have come as a reaction to the extreme allegorical interpretation practiced in some circles, an issue especially pertinent in the years after 1300. The well-known argument that the aniconic decoration of the Bible was due to reservations concerning figurative art for official books ${ }^{124}$ probably also played a role in the choice of the Haggadah, rather than the Bible, for the picture cycles. Such concerns may have led people seeking a suitable medium for the visual manifestation of this kind of understanding of the biblical narrative to prefer a small, mostly privately used book. This may explain why the two artistic idioms appear in two different types of books. Another reason for choosing the Haggadah instead of the Bible might have been the latter's length. Bibles are large and heavy, Haggadot small, thin, and light. Therefore, the addition of two quires of images did not present any difficulty in terms of size and weight. In Christian art biblical cycles were also rarely attached to volumes containing the entire biblical text. They appear instead as separate picture Bibles or adorn the opening pages of Psalters. ${ }^{125}$ These arguments might count as sufficient explanation of the two artistic types, but were it not for the different cultural backgrounds, we might expect the two idioms to merge at some point: a few figurative scenes in the Gothic style might have been inserted in the decoration program of some Bibles, whereas Islamicizing forms might have entered the decoration of the Haggadot. ${ }^{126}$ Yet apart from the aniconic Gothic elements in the Catalan Bibles, the two idioms in fact never meet. And it should be stressed that however "Gothic" these Bibles become, they always remain aniconic.

\section{Tudela and the Case of Joseph "the French"}

In light of the distinction suggested above between an aniconic and a figurative idiom and their respective cultural backgrounds, mention should be made of a further group of Bibles produced in Tudela during the early years of the fourteenth century. They are all related to Joshua ibn Gaon, a scribe, Masorete, and decorator. A native of the northern Castilian town of Soria, he moved at some point in his career 


\section{Aus rechtlichen Gründen steht diese Abbildung nicht im Open Access zur Verfügung}

18 Bible, calendar, Tudela, 1301-2. Paris, BNF héb. 21, fol. 2r

to Tudela. His signature appears on a number of manuscripts, of which two in Paris ${ }^{127}$ and another in Dublin ${ }^{128}$ are noteworthy. In his work, his decorative micrography stands out, but he also applied painted decorations. His decorations combine Gothic and Islamic features: grotesque animals, as well as naturalistic ones (Fig. 17), geometric interlace designs, architectural elements designed in the Mudejar style (Fig. 18), and carpet pages (Fig. 19). In some of his books a few nonfigurative text illustrations appear, which are referred to by Sed-Rajna as an early stage in the development of the later narrative mode in the Haggadah cycles. ${ }^{129}$ Like his Castilian contemporaries Joshua favored a repertoire of forms borrowed from Islamic art. His decorative style is unique, and in the way he combines Gothic and Islamic features he foreshadows the trend that was to flower later in Catalonia. Features known from early Spanish pre-Gothic art also appear as a source in his designs. ${ }^{130}$ Joshua ibn Gaon's art, rather than drawing on one particular cultural environment, arises from the climate of cultural exchange that was typical of late medieval Navarre in general and Tudela in particular. ${ }^{131}$ In Navarre both Jews and Mudejares suffered episodes of persecution less frequently than elsewhere in Spain, so their living conditions were comparatively better than in other areas of the peninsula. At the same time, the political atmosphere of Navarre, which apparently did not play a dominant part in the Jewish cultural struggle, provided a suitable ground for cultural exchange and mutual influence, with a consequent mixture of styles such as that found in the ibn Gaon books. Mudejar arts and crafts performed an important function in Tudela, the home of a large Mudejar community as well as a Jewish one, and the economic situation of the Muslim population was easier than in other regions of Christian Spain, where the Mudejares usually belonged to a poor lower class. ${ }^{132}$

One of the Bibles signed by Joshua, housed in Lisbon, is known commonly as the Cervera Bible. ${ }^{133}$ Joshua indicates that he executed the micrography in Tudela, in 1300, on behalf of a certain Sasson from Cervera. The main text, however, was written by one Samuel ben Abraham ibn Nathan, who copied the Bible while recovering in Cervera from a fractured leg, finishing the work three weeks before Joshua began his-hence the somewhat misleading label "Cervera Bible." ${ }^{134}$ It can be assumed that the manuscript was written in Cervera del Rio Alhama, a small town in Castile between Soria and Tudela known to have housed a Mudejar as well as a Jewish community. In any case it is likely that the illuminations were executed in Tudela together with the micrographic decoration.

The decorations include preliminary drawings of carpet pages, whose formal language is not related to the earlier 
Aus rechtlichen Gründen steht diese Abbildung nicht im Open Access zur Verfügung
19 Bible, carpet page, Paris, BNF héb. 21, fol. 1v micrographic carpets from Toledo but in a way foreshadows the much later examples of the Farhi and Foa Bibles. Since they remained unfinished and were not painted it is hard to say anything about them in detail. The paintings of the manuscripts were executed, as the very unusual occurrence of an artist's colophon informs us, by a certain Joseph Hatsarfati, "the French." ${ }^{35}$ We know nothing about Joseph Hatsarfati except his name, which indicates that he or his family was of French origin. It is not clear what Tsarfati ("French") meant, culturally speaking, in early fourteenth-century Tudela. Joseph may simply have been a French immigrant; Navarre adopted many Jews, subjected to repeated expulsions from France during the late thirteenth and the early fourteenth centuries. ${ }^{136}$ However, in the context of the controversy over philosophy, and from the point of view of the rationalists, Tsarfati acquired an explicitly negative connotation: it meant "tosafist" or Ashkenazic Jew from northern France. Jews from Provence, educated in the Judeo-Islamic tradition, were not included in this stereotype. ${ }^{137}$

Whether simply an immigrant indicating his origin or proudly hinting that his cultural identity was associated specifically with northern France, Joseph Hatsarfati created an

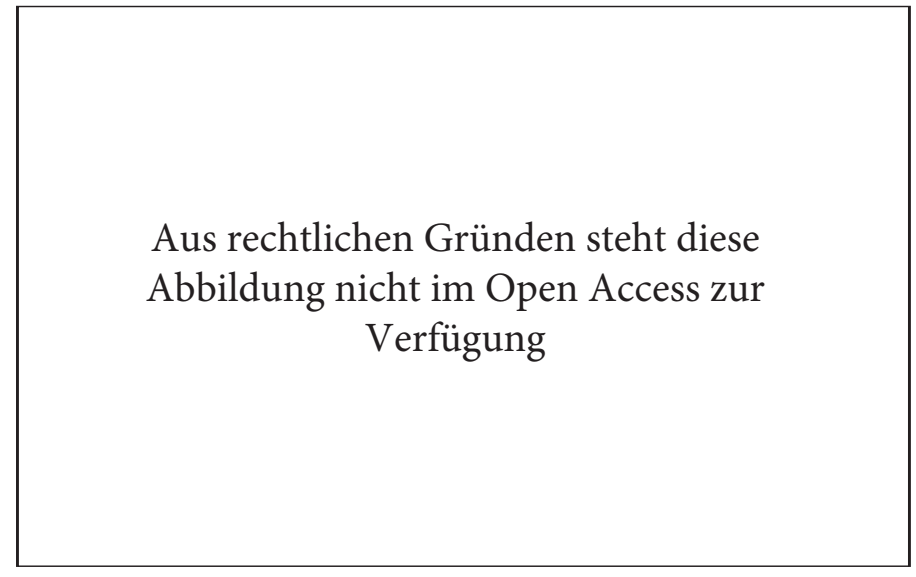

20 Cervera Bible, the Jonah story, Cervera and Tudela, 12991300. Lisbon, Bibl. Nac. ms Il. 72, fol. 304r

art that did not stem from the world in which the rest of the Hebrew Bibles evolved. His art seems to have been only partly influenced by the tradition of the Spanish Hebrew Bible. Christian sources, on the other hand, played a major role in 


\author{
Aus rechtlichen Gründen steht diese Abbildung nicht \\ im Open Access zur Verfügung
}

his work, and the most striking feature is his break with the aniconic tradition of Hebrew Bible decoration. Joseph frequently used figurative motifs and even a narrative composition (Fig. 20). The typical temple theme is missing, and instead we find an unparalleled painting of the menorah. ${ }^{138}$ Although it combines Gothic and Islamic motifs (Fig. 21), the rich, ornamental decoration shows a certain preference for Gothic design (Fig. 22). Joseph's approach is that of a welltrained, experienced miniaturist, and it apparently had a strong influence on Joshua, who nonetheless retained a more graphic character in his scribal decoration and remained faithful to the Sephardic tradition of aniconic Bible decoration and Islamic form. The fact that both were involved in the production of the Lisbon codex suggests that they knew each other.

\section{Maimonides's Texts Decorated}

Finally, a last small group of manuscripts should be mentioned. Early manuscripts of Maimonides's texts-"The Guide of the Perplexed," the Mishne Torah, and the Mishna commentary-were not decorated. Ever since their compilation, manuscripts of the Mishne Torah and the Mishna commentary contained instructive plans of the Temple (Fig. 15). Neither the philosophical content of "The Guide of the Perplexed" nor the Halakhic one of the law codex stimulated the creation of such a decoration program. It was more than a hundred years after Maimonides's scholarship had launched the controversy that his texts began to be embellished. When they were first decorated the original quarrel had long been forgotten; Maimonides's authority was unchallenged and no longer had much to do with social tensions and cultural transition. Decorations for manuscripts of his writings appear from the middle of the fourteenth century on, in Catalonia. With one exception, in a copy of "The Guide of the Perplexed" in Copenhagen, ${ }^{139}$ these are all of aniconic character, but in a pure Gothic style. They are either painted or executed in pen and limited to the area of ornamental decoration. ${ }^{140}$ The Copenhagen manuscript includes four figurative depictions, executed, as scholars believe, by 
Aus rechtlichen Gründen steht diese Abbildung nicht im Open Access zur Verfügung
22 Cervera Bible, "Sefer Mikhlol," fol. 435v

Christian artists, namely, Ferrer Bassa and his workshop. ${ }^{141}$ The manuscript is also rich in ornamental decoration, to which those of the other exemplars are stylistically related. When this kind of book was first decorated in mid-fourteenthcentury Catalonia, there was no pictorial tradition that illuminators, whether Christian or Jewish, could draw on. In creating a new one, they relied exclusively on the style common to their immediate artistic environment. This might explain why this group of manuscripts does not reflect the Islamicizing style with which the Judeo-Islamic tradition of the Hebrew Bibles is associated, although most of them preserve the tradition of aniconic decoration. After the middle of the fourteenth century, Spanish Jewish culture widely adopted the characteristics of Ashkenazic scholarship on the one hand and Maimonidean teaching on the other-as happened among Ashkenazic Jewry as well. The two worlds were no longer in contradiction, or at least not to the extent that they had been a few decades earlier.

Revisiting the two distinct types of Hebrew illuminated manuscripts from Spain in the light of the cultural-historical circumstances in which they were produced, particular phenomena, highlighted in this study, become evident. First, the coexistence of the aniconic and the narrative mode side by side, but never merging, is a noteworthy Sephardic phenomenon. Second, the preference for design borrowed from an Islamic repertoire of forms is striking considering the fact that all the known Sephardic Bibles were produced in Christian Spain. Whereas the Islamic heritage and Mudejar culture contributed to this phenomenon in the Castilian context (although it cannot serve as the sole explanation), in the case of the Catalan Bibles, this argumentation is simply misleading. Third, the preference for Islamic forms in Sephardic Bibles cannot be explained in terms of avoiding cultural exchange with Christianity either. The dependence in the Haggadot on biblical cycles from Christian pictorial sources proves the opposite.

It is therefore more likely that the explanation for these phenomena is to be looked for within the fabric of Jewish polemics and cultural change within Jewish society. The aniconic and Islamicizing decoration of the Bibles may thus be linked to the cultural values of circles associated with the Judeo-Islamic heritage and its scholarship, whereas the narrative biblical cycles seem embedded rather in Ashkenazic scholarship and the revival of Midrashic exegesis arising from an antirationalist worldview. That is, in my view, the use of Islamic decoration patterns and the adherence to aniconic ornamentation cannot be explained simply in terms of the centuries-long presence of Islam in most parts of the peninsula. Rather, the preference for Islamic styles mirrors a continuous dialogue with Islamic culture in an effort to keep alive those cultural values upheld by traditional Sephardic Jewry at a moment in history when those values were being challenged by other cultural trends.

Katrin Kogman-Appel, who earned a Ph.D. at Hebrew University, Jerusalem, is associate professor of art history. She has published articles on the Sephardic Haggadot in Gesta (1996), Zeitschrift für Kunstgeschichte (1997), and Speculum (2000) and is working on a book on the Sephardic Haggadot [Department of Arts, Ben Gurion University of the Negev, PO Box 653, Beer Sheva 84105, Israel].

\section{Frequently Cited Sources}

Garel, Michel, D'une main forte: Manuscrits hébreux des collections françaises, exh. cat., Bibliothèque Nationale de France, Paris, 1992.

Mann, Vivian B., Thomas F. Glick, and Jerrilyn D. Dodds, eds., Convivencia: Jews, Muslims and Christians in Medieval Spain, exh. cat., Jewish Museum, New York, 1992.

Narkiss, Bezalel, 1984, Kitve yad ivri'im me'uyarim (Hebrew illuminated manuscripts) (Jerusalem: Keter).

, 1997, The Golden Haggadah (London: British Library).

-, Alisa Cohen-Mushlin, and Anat Tcherikover, Hebrew Illuminated Manuscripts in the British Isles, vol. 1, The Spanish and Portuguese Manuscript (Jerusalem: Oxford University Press, 1982).

Schubert, Kurt, and Ursula Schubert, Jüdische Buchkunst, vol. 1 (Graz: Akademische Druck- und Verlaganstalt, 1984).

Sed-Rajna, Gabrielle, “Toledo or Burgos?” Journal of Jewish Art 2 (1975): 6-21.

\section{Notes}

Shorter versions of this article were delivered at the conference of the Association of Jewish Studies, Boston, December 2000, and in a lecture jointly organized by the Index of Christian Art and the Program in Medieval Studies at Princeton University, February 2001. I am indebted to Sara Lipton, whose comments helped me to refine many of my arguments. My thanks are also due to Harvey Hames, Boaz Huss, and Elisabeth Revel-Neher for having read earlier drafts, and to John Williams for discussing issues of Islamic influence on the arts in Spain. I thank Mira Reich for editing the English text and Perry Chapman and Lory Frankel of the Art Bulletin for their editorial assistance.

1. For some of the arguments in this article, see Katrin Kogman-Appel, Omanut yehudit bein islam lenatsrut: Itur siphre tanakh ivri'im besepharad (Jewish 
art between Islam and Christianity: The decoration of Hebrew Bibles from Spain (Tel Aviv: Hakibbutz Hameuchad, 2001), 148-70.

2. A recent study by Michael Batterman focuses on the evolution of the program as adorning a new type of book; Batterman, "The Emergence of the Spanish Illuminated Haggadah Manuscript,” Ph.D. diss., Northwestern University, Evanston, Ill., 2000

3. Bezalel Narkiss and his collaborators refer to these modes in terms of different decoration programs for different kinds of books: Bible manuscripts from 13th-century Castile are described as Hispano-Moresque, those of 14thcentury Catalonia represent an "oriental iconographic tradition," whereas the biblical picture cycles of the illuminated Passover Haggadot owe their development to the influence of Christian picture Bibles; Narkiss et al., 15 .

4. Gabrielle Sed-Rajna describes the emergence of extensive narrative cycles as a revolutionary innovation that began with slight hints of textual antifigurative illustration in a group of Bibles associated with the scribe and decorator Joshua ben Abraham ibn Gaon, who was active in Tudela abou 1300, and becoming fully developed in the Catalan illuminated Haggadot; see Sed-Rajna, "Hebrew Illuminated Manuscripts from the Iberian Peninsula," in Mann et al., 133-56; see also Sed-Rajna.

5. Joseph Gutmann similarly explains the two idioms in terms of a continuously changing cultural environment: the Islamicizing, aniconic decoration programs of the Hebrew Bibles reflect the heritage of "the first Golden Age for Jews in Muslim Spain" and displays the strong influence of Islamic art, whereas the Haggadah, as a private liturgical book, is viewed as a manifestation of interaction with the Christian environment; see Gutmann, Hebrew Manuscript Painting (New York: Braziller, 1978), 20

6. See, for example, Kurt Schubert and Ursula Schubert, 76-77, who see the decoration program of the Bible as reflecting a stricter observation of the biblical prohibition against images, under aniconic Islamic influence, than the Haggadah cycles. The former, a book of more official type, is often used during synagogue services, whereas the latter, restricted to the sphere of private service in Jewish homes, is believed to show a more liberal attitude.

7. Bible quotations follow the Oxford Study Bible, ed. M. Jack Suggs, Katherine Doob Sakenfeld, and James R. Mueller (Oxford: Oxford University Press, 1992).

8. For the rabbinic attitude to the Second Commandment during late antiquity, see, for example, Ephraim E. Urbach, "The Rabbinical Law of Idolatry in the Second and Third Centuries in the Light of Archeological and Historical Facts," Israel Exploration Journal 9 (1959): 149-65, 229-45; for the Middle Ages, see Schubert and Schubert 69-79; for a selection of sources on this matter, see Vivian B. Mann, Jewish Texts on the Visual Arts (Cambridge: Cambridge University Press, 2000). For a recent discussion on the notion of Judaism as an antivisual culture, see Kalman Bland, The Artless Jew: Medieval and Modern Affirmation and Denials of the Visual (Princeton: Princeton University Press, 2000).

9. See, for example, Maimonides, Mishne Tora (Jerusalem: Mossad Harav Kook, 1963), book 1, Hilkhot Avodat Kokhavim wehukot Ovdeha, 3:10; for an English translation of this statement, see Mann (as in n. 8), 23-24.

10. This group of manuscripts has been introduced by Leila Avrin, "The Illumination of the Moshe Ben Asher Codex of 895 C.E.," Ph.D. diss., University of Michigan, Ann Arbor, 1974; see also Narkiss, 1984, 23-28; idem Illuminations from Hebrew Bibles of Leningrad (Jerusalem: Magnes Press, Hebrew University, 1989); and, recently, Malachi Beit-Arie, Colette Sirat, and Mordechai Glatzer, Codices hebraicis litteris extrati quo tempore scripti fuerin exhibentes, vol. 1, Jusqu'á 1020 (Turnhout: Brepols, 1997). The most prominent examples are the so-called Ben Asher codex, Cairo, Karaite synagogue, and two manuscripts in the St. Petersburg Public Library, Firkovich coll., ms II B 17 and ms II B 19a.

11. Sephardic Jews are European Jews of the Iberian Peninsula; the Jews residing in Provence were culturally closely linked. After their expulsion from Spain (1492) and Portugal (1496), Sephardic Jews moved to various countries surrounding the Mediterranean Sea.

12. Ashkenazic Jews refer to Jews of modern Germany and Austria, as well as those of northern France and England.

13. A term introduced by Spanish cultural historians, especially Américo Castro, The Structure of Spanish History (Princeton: Princeton University Press, 1954).

14. See David Nirenberg, Communities of Violence: Persecution of Minorities in the Middle Ages (Princeton: Princeton University Press, 1996), 8-10; for discussion of scholarly attitudes to the history of the Jews under Christianity and Islam, see also Mark R. Cohen, Under Crescent and Cross: The Jews in the Middle Ages (Princeton: Princeton University Press, 1994), esp. xv-xvii.

15. Mann et al.

16. Thomas F. Glick, "Convivencia: An Introductory Note," in Mann et al., 1-9.

17. There are numerous publications on the political and cultural history of Spain in the Middle Ages. A prominent study is Joseph F. O'Callaghan, Histor of Medieval Spain (Ithaca, N.Y.: Cornell University Press, 1975); see also Jocelyn N. Hillgarth, The Spanish Kingdoms 1250-1516 (Oxford: Clarendon Press, 1978). For a focus on cultural exchange, see Thomas F. Glick, Islamic and Christian Spain in the Early Middle Ages (Princeton: Princeton University Press, 1979); or Angus MacKey, Spain in the Middle Ages: From Frontier to Empire 1000-1500 (New York: St. Martin's Press, 1977). More recent publications include Bernard F. Reilly, The Contest of Christian and Muslim Spain (Oxford: Blackwell, 1992); and Glick, From Muslim Fortress to Christian Castle: Social and
Cultural Change in Medieval Spain (Manchester: Manchester University Press, 1995).

18. A standard work on Spanish Jewry under Christian rule is Yitzhak Baer A History of the Jews in Christian Spain (Philadelphia: Jewish Publication Society of America, 1961); see also Maurice Kriegel, Les juifs à la fin du Moyen Âge dans l'Europe méditerranéenne (Paris: Hachette, 1979). Recently, more specific studies have appeared; see especially Yom Tov Assis, The Golden Age of Aragonese Jewry: Community and Society in the Crown of Aragon, 1213-1327 (London: Littman Library of Jewish Civilization, 1997); see also idem, "The Jews in the Crown of Aragon and Its Dominions," and Haim Beinart, "The Jews in Castile," in Moreshet Sepharad: The Sephardi Legacy, ed. Haim Beinart, vol. 1 (Jerusalem: Magnes Press, Hebrew University, 1992), 44-103, 11-43. For Navarre, see Beatrice Leroy, The Jews of Navarre in the Late Middle Ages (Jerusalem: Magnes Press, Hebrew University, 1985); Assis and Ramón Magdalena Yehude Navarra beshalhe yeme-habenayim (The Jews of Navarre at the end of the Middle Ages) (Jerusalem: Zalman Shazar Center for Jewish History, 1990). For a recent approach to the history of the Jews in medieval Europe in general, see Kenneth R. Stow, Alienated Minorities: The Jews of Medieval Latin Europe (Cambridge, Mass.: Harvard University Press, 1992); and for a comparison of Jewish life under Islamic and Christian rule (except Spain), see Cohen (as in n. 14)

19. Glick, 1979 (as in n. 17), 165-77; see also Glick (as in n. 16), 5; for a more recent but similar definition of acculturation, distinguishing between premodern, "inward" acculturation and modern, "outward" acculturation, the latter leading to secularization, see Ivan G. Marcus, Rituals of Childhood: Jewish Acculturation in Medieval Europe (New Haven: Yale University Press: 1996), 8-13.

20. Marseilles, Bibliothèque Municipale ms 1626, vols. II and III; lacking its first volume, this manuscript is presently divided between Marseilles and the St. Petersburg Public Library, Firkovich coll., ms II B 53. See Garel, no, 31; Sed-Rajna; and Sed-Rajna (as in n. 4), 136-37, For the latter St. Petersburg volume, see also Narkiss (as in n. 10), 69-70.

21. Sed-Rajna (as in n. 4), 136, has shown that Isaac was a member of an entire family of scribes known from documentary material.

22. See Sed-Rajna, with numerous reproductions and specific comparative examples from the Middle East, North Africa, and Spain.

23. Jerrilyn D. Dodds, ed., Al Andalus: The Art of Islamic Spain, exh. cat., Metropolitan Museum of Art, New York, 1992, cat. no. 48

24. Jerusalem, Jewish National and University Library ms heb. $4^{\circ} 790$. One leaf of this volume found its way to the Museo Sefaradi in Toledo; see Raphael Weiser, ed., Books from Sefarad, exh. cat., Jewish National and University Library and the Israel Museum, Jerusalem, 1992, 13. On this manuscript, see also Sed-Rajna, who argues convincingly that this type of carpet page originated in Toledo and was copied in Burgos; see also Sed-Rajna (as in n. 4), 137.

25. Parma, Biblioteca Palatina ms Parm 2668; Luisa Mortara Ottolenghi et al., Manoscritti biblici ebraici provenienti da biblioteche italiane publiche e private, exh. cat., Biblioteca Trivulzania, Milan, 1966, cat. no. 32; and Schubert and Schubert, 77. This manuscript is mistakenly listed among the group of Catalan Bibles in Narkiss et al., 56, as the "Parma Catalan Bible" of 1277. On 133 of the same publication, however, it is referred to as "the Bible of 1277 from Toledo."

26. Joseph Gutmann believes these pages to be a later, Catalan, addition Gutmann, "The Messianic Temple in Spanish Medieval Hebrew Manuscripts," in The Temple of Solomon: Archaeological Fact and Medieval Tradition in Christian, Islamic and Jewish Art (Missoula: Scholars Press, 1976), 134 n. 6. This assumption is not shared by other scholars who have examined the manuscript; see Carl O. Nordström, "Some Miniatures in Hebrew Bibles," in Synthronon (Paris: Klincksieck, 1968), 89-105; Thérèse Metzger, "Les objets du culte, le Sanc tuaire du Désert et le Temple de Jérusalem, dans les Bibles hébraïques médiévales enluminées en Orient et en Espagne," pts. 1 and 2, Bulletin of the John Rylands Library 52 (1969-70): 397-436, 53 (1970-71): 167-209; SedRajna, 15; and Schubert and Schubert, 77. Should Gutmann be correct, and the pages of the Parma Bible a later addition modeled after those of the Perpignan Bible of 1299 (see below), the latter would be the earliest exemplar and the temple program itself the creation of a Provençal illuminator. It is important to note that this form represents the earliest type, whether produced for the first time in Castile or Roussillon. There is, however, no evidence for Gutmann's suggestion. Recently I examined the manuscript, its decoration and codicology, none of which support Gutmann's theory. Yet cannot definitively claim the opposite. The manuscript lacks other painted illumination, its decoration being limited to micrography and penwork done by the scribe or the Masorete. I therefore found myself unable to reach a final conclusion. The codicological diagnosis leads to the assumption that the painted pages were indeed planned originally to contain illustrations. For a detailed description of the findings, see Kogman-Appel (as in n. 1), 71-76.

27. Joseph Gutmann, "When the Kingdom Comes: Messianic Themes in Medieval Jewish Art," Art Journal 27 (1967-68): 168-75; idem (as in n. 5), 19, 50-51; Metzger (as in n. 26); Narkiss, 1984, 33; Narkiss et al., 102; Schubert and Schubert, 81-82; and Elisabeth Revel-Neher, Le témoignage de l'absence: Les objets du Sanctuaire à Byzance et dans l'art juif du XIe au XVe siècle (Paris: De Bonnard, 1998), 97-117.

28. Profiate Duran, Ma'aseh Ephod, 11-12, quoted in Joseph Gutmann, “Masora figurata in the Mikdashyah: The Messianic Solomonic Temple in a 14th-century 
Spanish Hebrew Bible," in Eighth Intermational Congress of the International Organization for Masoretic Studies (Missoula: Scholars Press, 1988), 71.

29. For an attempt at iconographic classification, see Metzger (as in n. 26). Cecil Roth and Bezalel Narkiss searched for the sources of this program in ancient mosaics from Israel and early medieval Middle-Eastern Hebrew manuscripts; see, for example, Roth, "Jewish Antecedents of Christian Art," Journal of the Warburg and Courtauld Institutes 16 (1953): 24-44; and Narkiss, "The Scheme of the Sanctuary from the Time of Herod the Great," Journal of Jewish Art 1 (1974): 6-15. Gutmann (as in n. 26), 125-26, and Metzger (as in n. 26), 414 , rejected their conclusions, because of an apparent lack of visual similarity between the ancient Middle-Eastern and the later Sephardic examples. See also more recently Bianca Kühnel, who looks for models of the temple depictions in Latin manuscript illumination; Kühnel, "Jewish and Christian Art in the Middle Ages: The Dynamics of a Relationship," in Juden und Christen zur Zeit der Kreuzzüge, ed. Alfred Haverkamp (Sigmaringen: Jan Thorbecke, 1999), 6-16.

30. Nordström (as in n. 26).

31. On the conquest of Toledo and its consequences in general, see O'Callaghan (as in n. 17), 204-5. For a history of the Mudejares in particular see Leonard P. Harvey, Islamic Spain 1250 to 1500 (Chicago: University of Chicago Press, 1992)

32. Harvey (as in n. 31), 12, 68-69.

33. Teofilo F. Ruiz, Crisis and Continuity: Land and Town in Late Medieval Castile (Philadelphia: University of Pennsylvania Press, 1994), 281.

34. Beinart (as in n. 18), 11-43; for Burgos, see also Ruiz (as in n. 33), 272.

35. For a survey, see, for example, J. Dominguez Bordona, Spanish Illumination (New York: Hacker Art Books, 1969), 37-42.

36. For the arts of the Mudejares in general, see Gonzálo M. Borrás Gualis, El arte mudéjar (Teruel: Instituto de Estudios Turolenses, 1990); for Toledo in particular, see recently David Raizman, "The Church of Santa Cruz and the Beginnings of Mudéjar Architecture in Toledo," Gesta 38, no. 2 (1999): 128-41, listing earlier literature.

37. Jerrilyn D. Dodds, "Mudéjar Tradition and the Synagogues of Medieval Spain: Cultural Identity and Cultural Hegemony," in Mann et al., 115-18 listing all the earlier relevant literature. To this should be added Meir BenDov, Bate kneset besepharad (Synagogues in Spain) (Tel Aviv: Dvir, 1989).

38. Sabiha Khemir, "The Arts of the Book," in Dodds (as in n. 23), 115-26.

39. See, for example, the Bible in the St. Petersburg Public Library, Fir kovich coll. ms II B 19a; Narkiss, 1984, pl. 2; and Narkiss (as in n. 10), fig. 3. 40. See above at $n .22$

41. Bibliothèque Nationale de France (BNF) héb. 7; Garel, no. 50. According to Joseph Gutmann, the model-copy relationship was the other way around; see $n$. 26 above.

42. Gutmann (as in n. 5), 51 .

43. The inscription "Jesus Maria" is the ex-libris of the Convent de l'Oratoire in Paris, which owned the manuscript in the 17 th century. I am indebted to Michel Garel for this information.

44. Copenhagen, Kogelige Bibliotek heb. II; Bezalel Narkiss and Gabrielle Sed-Rajna, Index of Jewish Art: Iconographical Index of Hebrew Illuminated Manuscripts, vol. 5, Illuminated Manuscripts of the Collection at the Royal Library, Copenhagen (Jerusalem: Center of Jewish Art, 1994).

45. See, for example, Narkiss et al., 101-21; and Kogman-Appel (as in n. 1), $118-47$.

46. Formerly Sassoon coll. ms 368; the Farhi Bible was not sold and is still part of the Sassoon collection. Its current location is unknown; it is not accessible for examination. I thank R. David Sassoon, of Jerusalem, for allowing me to use his photographs for study. Sybil Mintz, "The Carpet Pages of the Spanish-Hebrew Farhi-Bible," in The Medieval Mediterranean: CrossCultural Contacts, ed. Marilyn J. Chiat and Kathryn L. Reyerson (St. Cloud, Minn.: North Star Press of St. Cloud, 1988), 26-37. Mintz suggests a Barcelonian provenance.

47. Narkiss, 1984, 99

48. BNF arabe 385 ; Dodds (as in n. 23 ), cat. no. 85

49. Madrid, Biblioteca de El Escorial ms 1740, fol. 1v; Natascha Kubisch, Die Synagogue Santa Maria la Blanca in Toledo: Eine Untersuchung zur maurischen Ornamentik (Frankfurt: Peter Lang, 1995), pl. 22a

50. At first sight, these motifs seem so incongruous that Mintz (as in n. 46) assumes they were added by a different hand. However, similar floral designs in the same colors, clearly belonging to the world of Gothic style, are incorporated in the carpets themselves and appear as background to the more dominant interlace patterns.

51. Foa Bible, Paris, library of the Compagine des Prêtres, St-Sulpice ms 1933; Michel Garel, "The Foa Bible," Journal of Jewish Art 6 (1979): 78-85. On the basis of stylistic observations and heraldic signs incorporated in the design of the carpet pages, Garel assumes that it was produced about the $1380 \mathrm{~s}$ in the region of Barcelona.

52. Garel (as in n. 51), figs. 3-7, 10 .

53. See, for example, Narkiss et al., figs. 312, 324

54. Narkiss, 1997, 64

55. As described, for example, in detail by O'Callaghan (as in n. 17), 106.

56. Philip Daileader, True Citizens: Violence, Memory, and Identity in the Medieval Community of Perpignan, 1162-1397 (Leiden: E. J. Brill, 2000), 131.

57. Elena Lourie, "Anatomy of Ambivalence: Muslims under the Crown of Aragon in the Late Thirteenth Century," in Crusade and Colonisation: Muslims,
Christians and Jews in Medieval Aragon (Aldershot, Eng.: Variorum, 1990), vol. 7, 17; and Nirenberg (as in n. 14), 22

58. Nirenberg (as in n. 14), 22 n. 14.

59. David Romano, "Musulmanes residentes y emigrantes en la Barcelona de los siglos XIV-XV," Al-Andalus 41 (1976): 49-88; and Nirenberg (as in n. 14), 22.

60. Yom Tov Assis, "Diplomatim yehudim mearagonia beartsot haislam" (Jewish diplomats from Aragon in Muslim lands [1213-1327]), Sephunot 3, no. 18 (1985): 11-34; see also Nirenberg (as in n. 14), 22 n. 14.

61. Yom Tov Assis, "Yehude Bartselona basachar hayami im hamizrach" (The Jews of Barcelona in maritime trade with the East), in Exile and Diaspora, ed. Aharon Mirsky, Abraham Grossman, and Yosef Kaplan (Jerusalem: Ben Zvi Institute, 1988), 257-83; and idem, Jewish Economy in the Medieval Crown of Aragon, 1213-1327 (Leiden: E. J. Brill, 1997), 101-3.

62. For Italian influences in Christian Catalan art, see C. R. Dodwell, The Pictorial Arts of the West 800-1200, Pelican History of Art (New Haven: Yale University Press, 1993), 256; and Dominguez Bordona (as in n. 35), 48. For Italian stylistic features in figurative illustrations of Hebrew manuscripts, see Narkiss, 1997, 50

63. For example, the Bird's Head Haggadah in Jerusalem, Israel Museum ms $180 / 57$, or Joel ben Simeon's Haggadah in London, British Library ms Add. 14762. The same is true for all the Ashkenazi and Italian Haggadot with only two exceptions: the Second Nuremberg Haggadah, Jerusalem, Schocken Library ms 24087, and its sister manuscript, the Yahudah Haggadah, Jerusalem, Israel Museum ms 180/50; Katrin Kogman-Appel, Die zweite Nürnberger und die Jehuda Haggada: Jüdische Illustratoren zwischen Tradition und Fortschritt (Frankfurt: Peter Lang, 1999). These two manuscripts exhibit entire biblical cycles, and these are placed in the margins with a remarkably high degree of adjustment to the contents of the Haggadah and juxtaposed with numerous scenes specifically related to the Haggadah text.

64. London, Brit. Lib. ms Add. 14761; Narkiss et al., 78-84, figs. 209-45; and Jerusalem, Israel Museum ms 180/41 (formerly Sassoon coll. ms 514); Iris Fishof, "A Legacy on Parchment: The Sassoon Spanish Haggadah," Israel Museum Journal 10 (1992): 9-14.

65 . One such example is the so-called Mocatta Haggadah, London, University College Library ms 1; Narkiss et al., 52-55, figs. 105-22; and Leila Avrin, "The Mocatta Haggadah and Other Works by the Master of the Catalan Mahzor," in Hebrew Studies: Papers Presented at a Colloquium on Resources for Hebraica (London: British Library, 1989), 139-48. Another example is preserved in the monastery of Poblet; José R. M. Nom de Deu, "The Poblet Haggadah: An Unknown Fourteenth-Century Illuminated Sephardic Manuscript," Jewish Art 18 (1992): 109-16.

66. Narkiss et al., 57-100. The Catalan Haggadot were introduced by Julius von Schlosser and David H. Müller, Die Sarajevo Haggada: Eine spanisch-jüdische Bilderhandschrift des Mittelalters (Vienna: Alfred Holder, 1898). Other studies dealing primarily with a basic analysis of the artistic background are Cecil Roth, The Sarajevo Haggadah (1963; reprint, New York: Harcourt, Brace and World, 1968); Bezalel Narkiss, The Golden Haggadah: A Fourteenth Centur Illuminated Hebrew Manuscript in the British Museum; Facsimile and Introduction (London: Eugrammia Press, 1970); and Narkiss et al., 42-100. See also Joseph Gutmann, "The Illuminated Medieval Passover Haggadah-Investigations and Research Problems," Studies in Bibliography and Booklore 7 (1965): 3-25; Gabrielle Sed-Rajna, The Hebraic Bible in Medieval Illuminated Manuscripts (Tel Aviv: Steimatzky, 1987); and recently, idem, "Haggadah and Aggadah: Reconsidering the Origins of the Biblical Illustrations in Medieval Hebrew Manuscripts," in Byzantine East, Latin West: Art-Historical Studies in Honor of Kurt Weitzmann, ed. Doula Mouriki and Christopher Moss (Princeton: Princeton University Press, 1995), 415-23

67. Narkiss et al., 45-51, figs. 79-104

68. Sarajevo, National Museum; for a facsimile edition, see Eugen Werber, The Sarajevo Hagradah (Sarajevo: Svjetlost, 1999).

69. Brit. Lib. ms Add. 27210; for a facsimile edition see Narkiss (as in n. 66); see also recently, Narkiss, 1997; and Narkiss et al., 58-66, figs. 123-54.

70. Brit. Lib. ms Or. 2884; Narkiss et al., 67-77, figs. 155-208.

71. Manchester, John Rylands University Library heb. 6; Raphael Ben Zvi Mordehai Halevy, The Rylands Haggadah (London: Thames and Hudson, 1988); and Narkiss et al., 86-93, figs. 250-82.

72. Brit. Lib. ms Or. 1404; Narkiss et al., 93-98, figs. 283-305.

73. Narkiss (as in n. 66); idem, 1997; Sed-Rajna, 1987 (as in n. 66); and recently, idem, 1995 (as in n. 66).

74. See, for example, Katrin Kogman-Appel, "Der Exoduszyklus der Sarajevo-Haggada: Bemerkungen zur Arbeitsweise spätmittelalterlicher jüdischer Illuminatoren und ihrem Umgang mit Vorlagen," Gesta 35, no. 2 (1996): 111-27; and idem, "The Picture Cycles of the Rylands Haggadah and the So-Called Brother Haggadah and Their Relation to the Western Tradition of Old Testament Illustration," Bulletin of the John Rylands University Library 79 no. 2 (1997): 1-19. For some of the Christian sources, but strictly from the viewpoint of recensional history, see Narkiss (as in n. 66); idem, 1997; and Sed-Rajna, 1987 (as in n. 66)

$\rightarrow$ Katrin Kogman-Appel, "The Sephardic Picture Cycles and the Rabbinic Tradition: Continuity and Innovation in Jewish Iconography," Zeitschrift für Kunstgeschichte 60, no. 4 (1997): 451-81.

76. Katrin Kogman-Appel, "Coping with Christian Pictorial Sources: What Did Jewish Miniaturists Not Paint?” Speculum 74, no. 4 (2000): 816-58. 
77. More examples are listed and discussed in Kogman-Appel (as in n. 75). 78. Similarly also in Brit. Lib. ms Or. 2884, fol. 4v; Narkiss et al., fig. 161. 79. For specific comparisons, see Narkiss, 1997, 50-54.

80. Targum Pseudo Jonathan, on Gen. 28:11; Ernest G. Clarke et al., eds., Targum Pseudo Jonathan of the Pentateuch: Text and Concordance (Hoboken, N.J.: Ktav Publishing House, 1984)

81. An early example from Spain is found in the Rippoll Bible, 10th century, Vatican, Biblioteca Apostolica lat. 5729, fol. 3v; Wilhelm Neuss, Die katalanische Bibelillustration um die Wende des ersten Jahrtausends und die altspanische Buchmalerei (Bonn: K. Schroeder, 1922), fig. 11. For later examples, se London, Brit. Lib. ms Cotton Nero C IV, fol. 5r, and the Peterborough Psalter in Brussels, Bibliothèque Royale ms 9961-2, fol. 92v; Lucy Freeman Sandler, The Peterborough Psalter in Brussels and Other Fenland Manuscripts (London: Harvey Miller, 1974), pl. 59. See also Kogman-Appel (as in n. 75), 467-68.

82. Narkiss (as in n. 66), 43. This term implies Islamic characteristics. Moresque, related to morsos, is, as such, a term for Spain's Muslim population, which, due to its negative connotations, is not favored in modern scholarship. Narkiss discerned "Islamic and Oriental" influences in the style of the manuscript-probably his justification for the label-but did not explain this designation further.

83. In the 1982 catalogue of Hebrew illuminated manuscripts from Spain (Narkiss et al., 51), the stylistic features of this Haggadah are described in more detail and linked to the art of manuscript painting at the court of Alfonso X. Although this link is correct, the term Moresque is still applied to the style itself and to the manuscript.

84. They were examined and discussed by Karl O. Werckmeister, "Islamische Formen in spanischen Miniaturen des 10. Jahrhunderts und das Problem der mozarabischen Buchmalerei," in L'occidente e l'Islam nell'alto medioevo: Settimane di Studio del Centro italiano di sull'alto medioevo (Spoleto: Centro Italiano di Studi sull'Alto Medioevo, 1965), 933-67.

85. Katrin Kogman-Appel, "The Place of Biblical Narrative in Iberian Jewish Culture of the Late Middle Ages," paper delivered at the 89th annual conference of the College Art Association, Chicago, Feb. 2001; article in preparation

86. Maimonides (as in n. 9), bk. 2, Hilkhot Mezuzah, chaps. 5, 6

87. For the so-called Maimonidean controversy, see Daniel J. Silver, Maimonidean Criticism and the Maimonidean Controversy 1180-1240 (Leiden: E. J Brill, 1965); Bernard Septimus, Hispano-Jewish Culture in Transition: The Career and Controversies of Ramah (Cambridge, Mass.: Harvard University Press, 1982); Kriegel (as in n. 18), 145-79; and Charles Touati, "Les deux conflits autour de Maimonide et des études philosophiques," Cahiers de Fanjeaux 12 (1977): 173-84.

88. Silver (as in n. 87), $148-49$

89. On this phase of the controversy, see Silver (as in n. 87), 41; Charles Touati, Prophètes, talmudistes, philosophes (Paris: Les Éditions du Cerf, 1990), 201-17; Assis, 1997 (as in n. 18), 305-7; and Ram Ben-Shalom, "Communication and Propaganda between Provence and Spain: The Controversy over Extreme Allegorization," in Communication in the Jewish Diaspora: The PreModern World, ed. Sophia Menache (Leiden: E. J. Brill, 1996), 171-225. For details and two different views on the political issues involved in the banning, see Marc Saperstein, "The Conflict over the Rashba's Herem on Philosophical Study: A Political Perspective," Jewish History 1, no. 2 (1986): 27-38; and Ben Shalom, "The Ban Placed by the Community of Barcelona on the Study of Philosophy and Allegorical Preaching-a New Study," Revue des Études Juives 159 (2000): 387-404

$\rightarrow$ 30. Touati (as in n. 89), 205, 210-12; and Ben-Shalom, 1996 (as in n. 89).

91. For a view that focuses on this particular aspect of the controversy and seeks its actual roots in the gap between rationalistic and Kabbalistic worldviews, see Harvey J. Hames, The Art of Conversion: Christianity and Kabbalah in the Thirteenth Century (Leiden: E. J. Brill, 2000), 31-82.

92. For an English text, see The Zohar, trans. Harry Sperling and Maurice Simon (London: Soncino Press, 1934); on the Book of Zohar, see, for example, Gershom Scholem, Major Trends in Jewish Mysticism (New York: Schocken Books, 1961); and Yehuda Liebes, Studies in the Zohar (Albany: State University of New York Press, 1993).

93. Nordström (as in n. 26). For a summary of this topic including quotes from the relevant sources, see also Narkiss et al., 100-104.

94. Revel-Neher (as in n. 27), 61-117.

95. Kogman-Appel (as in n. 1), 78-80.

96. On this issue, see S. M. Stern, "Autographs of Maimonides in the Bodleian Library," Bodleian Library Record 5 (1955): 180-202.

97. Oxford, Bodleian Library ms Poc. 295; Rachel Wischnitzer, "Maimonides's Drawings of the Temple," Journal of Jewish Art 1 (1974): 16-27. See al. $\rightarrow$ Revel-Neher (as in n. 27), 91

98. See above at n. 29 .

99. Paris, BNF, héb. 25; Garel, 58-60.

100. Menahem Hameiri, Kiryat Sepher (Jerusalem: Hamesore Press, 1956), 48; see also Sed-Rajna, 7-8; and Garel, no. 31 .

101. This view, which establishes an iconographic link between the Toledan Bibles and those from Roussillon, provides a further argument against Gutmann's assumption that the decoration of the Parma Bible was added later; see $n$. 26 above.

102. Schlosser and Müller (as in n. 66); Narkiss (as in n. 66); Narkiss et al., 57-101; Schubert and Schubert, 98-122; and Narkiss, 1997. Earlier research, especially by Narkiss and Schubert and Schubert, referred to these interpolations as traces of the late antique tradition of Jewish narrative art and interpreted them in terms of recensional history. On the recension method in the context of the Haggadah cycles and my own view on this matter, see Kogman-Appel, 1996 (as in n. 74), 111-14.

103. For background and sources, see Abraham Grossman, "Biblical Exegesis in Spain during the 13th-15th Centuries," in Beinart (as in n. 18), 138 104. Ibid., 142-43.

105. Targum Pseudo Jonathan (as in n. 80), on Gen. 43:33; Genesis Rabbah 92:5; Jacob Neusner, Genesis Rabbah: The Judaic Commentary to the Book of Genesis; A New American Translation, vol. 3 (Atlanta: Scholars Press, 1985), 288.

106. Rashi on Gen. 43:33, in The Pentateuch and Rashi's Commentary: A Linear Translation into English, trans. R. Abraham Ben Isaiah and R. Benjamin Sharfman (New York: S. S. and R.; Philadelphia: Jewish Publication Society, 1949).

107. Yalkut Shimoni latorah, ed. Dov. Heimann et al., vol. 3 (Jerusalem: Levin Epstein, 1967), no. 150

108. Günter Stemberger and Hermann L. Strack, Einleitung in Talmud und Midrasch (Munich: Beck, 1982), 315

109. Rabenu Bahye: Bi'ur al hatora, on Gen. 43:33, vol. 3, ed. Haim Chevel (Jerusalem: Mossad Harav Kook, 1966), 346.

110. See Cohen (as in n. 14), xv-xvii.

111. For details, see Cohen (as in n. 14), xvi.

112. Ibid.

113. Dov Septimus, "Tachat Edom welo tachat Ishmael-gilgulo shel ma'amar" (Under Edom and not under Ismael-the history of a saying), Zion 47 (1982): 107

114. They are discussed by Septimus (as in n. 113), 103-11; and E. Gutwirth, "Hispano-Jewish Attitudes to the Moors in the Fifteenth Century," Sefarad 49 (1989): 237-62.

115. Rabenu Bahye (as in n. 109), vol. 3, 439-40; and Septimus (as in n 113), 104.

116. Georges Vajda, "Un chapître de l'histoire du conflit entre la Kabbale et la Philosophie: La polémique anti-intellectualiste de Joseph ben Shalom Ashkenazi de Catalogne," Archives d'Histoire Doctrinale et Littéraire du Moyen Âge 23 (1956): 45-144.

117. Gutwirth (as in n. 114).

118. Baer (as in n. 18), vol. 1, 30-38.

119. Kriegel (as in n. 18), 152-55; on Kabbalistic elites, on the other hand, see Moshe Idel, "Kabbalah and Elites in Thirteenth-Century Spain," Mediterranean Historical Review 9 (1994): 5-19.

120. Described in detail in Baer (as in n. 18), vol. 1, 243-305.

121. Assis, 1997 (as in n. 87), 237-40.

122. Septimus (as in n. 87)

123. Moshe Idel, Language, Torah, and Hermeneutics in Abraham Abulafia (Albany: State University of New York Press, 1989).

124. See above at n. 6 .

125. Prominent examples are the Pamplona Bibles, ca. 1200, Navarre; see François Bucher, The Pamplona Bibles (New Haven: Yale University Press, 1970); and the Padua Bible, ca. 1400, northern Italy; see Gianfranco Folena and Gian Lorenzo, Bibbia istoriata padovana della fine del trecento (Venice: N. Pozza, 1962).

126. The only echo of Islamicizing forms in the Catalan Haggadot are interlace patterns in some of the depictions of the matzah, for example, in the Mocatta Haggadah (as in n. 65), fol. 43r; Narkiss et al., fig. 118; and the Golden Haggadah (as in n. 54), fol. 44v; Narkiss et al., fig. 153. Their composition indicates carpet pages as models. Nevertheless, only a few indeed contain interlace patterns. Others are entirely Gothic in style, as, for example, London, Brit. Lib. ms Add. 14761, fol. 61r; Narkiss et al., fig. 240. For a complete listing of representatives of the two stylistic trends, see Batterman (as in n. 2), chap. 4. For an interpretation of the matzah panels as a visualization of the Divine Presence in terms of Kabbalah, see ibid. Such strong links to Kabbalah are not easily reconcilable with Batterman's own view of the declining class of court Jews and their claims, which he believes to be manifest in the decoration program of the Haggadot.

127. BNF héb. 20; Bezalel Narkiss and Gabrielle Sed-Rajna, "La première Bible de Josué ben Abraham Ibn Gaon," Revue des Études Juives 130 (1971) 255-69; Garel, no. 45; and Gabrielle Sed-Rajna, "Hebrew Manuscripts from Toledo and Tudela: Creation or Transmission?" in Abraham ibn Ezra and His Age, ed. Fernando Diaz Esteban (Madrid: Asociacion Española de Orientalistas, 1990), 301-7; and BNF héb. 21; Garel, no. 46.

128. Dublin, Trinity College Library ms 16; Narkiss et al., 30-32, figs. $28-42$.

129. See above at n. 4 .

130. For example, Narkiss and Sed-Rajna (as in n. 127), 268, have shown that the depiction of Noah's ark in BNF héb. 20, fol. 13r, follows those in manuscripts of the commentary of Beatus of Liébana, for example, Valladolid, Biblioteca S. Cruz, fol. 16; Neuss (as in n. 81), fig. 91; Madrid, Biblioteca Nacional ms B 31, fol. 119 (from S. Isidoro); Neuss (as in n. 81), fig. 93; New York, Pierpont Morgan Library ms 644, fol. 79r; John W. Williams, Early Spanish Manuscript Illumination (New York: Braziller, 1977), 17-20, pl. 14. For Beatus manuscripts, see more recently Williams, The Illustrated Beatus: A Corpus of the Illustrations of the Commentary on the Apocalypse (London: Harvey Miller, 1994); and Mireille Mentré, Illuminated Manuscripts of Medieval Spain (London: Thames and Hudson, 1996). 
131. At least before the outbreak of the shepherds' movement in 1320; see Nirenberg (as in n. 14), 43-126.

132. Harvey (as in n. 31), 139

133. Lisbon, Biblioteca Nacional ms Il. 72

134. According to Narkiss et al., 17, the manuscript was written in the Castilian town of Cervera not far from Toledo and is reckoned among the group of Castilian Hebrew Bibles. It does not have much in common with these, however. Thérèse Metzger, who published Joshua's micrographic colophons in 1992 and was the first to associate the manuscript with Tudela and Joshua ibn Gaon, believes it to have been written in Cervera in Catalonia located less than three weeks' journey from Tudela; Metzger, "Josué ben Abraham ibn Gaon et la masora du Ms. Iluminado 72 de la Biblioteca nacional de Lisbonne," Codices manuscripti 15, no. 5 (1990): 1-27.

135. Fol. 434r; Gutmann (as in n. 5), pl. 10.
136. On the history of the Jews of Navarre, see Assis and Magdalena (as in n. 18); and Leroy (as in n. 18).

137. Septimus (as in n. 87), 64.

138. Narkiss, 1984, pl. 6; the iconography of this depiction is discussed in Revel-Neher (as in n. 27), 93-94.

139. Copenhagen, Roy. Lib. heb. xxxvI; Narkiss, 1984, pl. 18; and Narkiss and Sed-Rajna (as in n. 44).

140. For an exception-picturing a philosophical concept-see Garel, 41-

141. Millard Meiss, "Italian Style in Catalonia and a Fourteenth-Century Catalan Workshop," Journal of the Walters Art Gallery 4 (1941): 45-87; Gabrielle Sed-Rajna, "Hebrew Manuscripts of Fourteenth Century Catalonia and the Workshop of the Master of St. Mark," Jewish Art 18 (1992):117-28; and Narkiss et al., 124 . 